This manuscript version is the "Accepted Author Manuscript" - the final published article detail is below and may be accessed via the DOI link provided:

Freitas, J.G., Rivett, M.O., Roche, R.S., Tellam, J.H., Durrant, M., Walker, C., 2015. Heterogeneous hyporheic zone dechlorination of a TCE groundwater plume discharging to an urban river reach. Science of the Total Environment 505, 236252, http://dx.doi.org/10.1016/j.scitotenv.2014.09.083

\title{
Highlights
}

- TCE dechlorination was often partial, or absent, but rarely complete to ethane

- Chlorine number reduction provided a convenient quantitative attenuation metric

- Dechlorination is driven by transient hyporheic zone flow and organic matter input

- Dechlorination is inhibited by no hyporheic zone, oxic and high sulfate conditions

- Attenuation will be poorly constrained without detailed reach-scale investigation

\section{Heterogeneous hyporheic zone dechlorination of a TCE groundwater plume discharging to an urban river reach}

\author{
Juliana G. Freitas ${ }^{1 *}$, Michael O. Rivett ${ }^{2}$, Rachel S. Roche ${ }^{2}$, Megan Durrant (neé \\ Cleverly) ${ }^{2,3}$, Caroline Walker ${ }^{2,4}$, John H. Tellam ${ }^{2}$
}

\footnotetext{
${ }^{1}$ Federal University of São Paulo (UNIFESP), Rua Prof. Artur Riedel, 275 - Jd. Eldorado -
} Diadema, SP - 09972-270, Brazil

${ }^{2}$ School of Geography, Earth and Environmental Sciences, University of Birmingham, Birmingham, B15 2TT, UK. 
${ }^{3}$ Now at: Mott MacDonald, Demeter House, Station Road, Cambridge, CB1 2RS

${ }^{4}$ Now at: AMEC Environment \& Infrastructure, Prospect House, 32 Sovereign Street, Leeds, LS1

4BJ, UK

*corresponding author

\begin{abstract}
The typically elevated natural attenuation capacity of riverbed - hyporheic zones is expected to decrease chlorinated hydrocarbon $(\mathrm{CHC})$ groundwater plume discharges to river receptors through dechlorination reactions. The aim of this study was to assess physico-chemical processes controlling field-scale variation in riverbed - hyporheic zone dechlorination of a TCE groundwater plume discharge to an urban river reach. The 50-m long pool - riffle - glide reach of the River Tame in Birmingham (UK) studied is a heterogeneous high energy river environment. The shallow riverbed was instrumented with a detailed network of multilevel samplers. Freeze coring revealed a geologically heterogeneous and poorly sorted riverbed. A chlorine number reduction approach provided a quantitative indicator of $\mathrm{CHC}$ dechlorination. Three sub-reaches of contrasting behaviour were identified. Greatest dechlorination occurred in the riffle sub-reach that was characterised by hyporheic zone flows, moderate sulphate concentrations and $\mathrm{pH}$, anaerobic conditions, low iron, but elevated manganese concentrations with evidence of sulphate reduction. Transient hyporheic zone flows allowing input to varying riverbed depths of organic matter is anticipated to be a key control. The glide sub-reach displayed negligible dechlorination attributed to the predominant groundwater baseflow discharge condition and absence of hyporheic zone, transition to more oxic conditions and elevated sulphate concentrations expected to inhibit dechlorination. The tail-of-pool-riffle sub-reach exhibited patchy dechlorination that was attributed to sub-reach complexities including significant flow bypass of a low permeability, high organic matter, silty unit of high dechlorination potential. A process-based conceptual model of reach-scale dechlorination variability was developed. Key findings of practitioner relevance were: riverbed - hyporheic zone $\mathrm{CHC}$ dechlorination may provide only a partial, patchy barrier to $\mathrm{CHC}$ groundwater plume discharges to a surface water receptor; and, monitoring requirements to assess the variability in $\mathrm{CHC}$ attenuation within a reach are expected to be onerous. Further research on transient hyporheic zone dechlorination is recommended.
\end{abstract}

Keywords: Groundwater-surface water interaction; Trichloroethene (TCE); Chlorinated hydrocarbon (CHC); Natural attenuation; Hyporheic zone; Dechlorination 


\section{Introduction}

Chlorinated hydrocarbons (CHCs) such as the degreasing solvent trichloroethene (TCE) have caused significant groundwater contamination (Pankow and Cherry, 1996; Rivett et al., 2006; Vedrina-Dragojević and Dragojević, 1997). Historical poor handling and disposal of CHC solvents has resulted in frequent releases to the subsurface that typically pose long-term threats to groundwater quality. Dissolved plumes in groundwater may prove persistent, especially when plumes emanate from dense non-aqueous phase liquid (DNAPL) source zones (Pankow and Cherry, 1996; Rivett et al., 2014). Plumes may also be lengthy due to their modest natural attenuation in many aquifer environments (McGuire et al., 2004). As such, dissolvedphase CHC plumes may hold significant potential to discharge to surface waters where they may pose risks to ecosystems and human receptors (Conant et al., 2004; Ellis and Rivett, 2007; McGuire et al., 2004; McKnight et al., 2010; Moran et al., 2007; Weatherill et al., 2014). Our focus is upon the final opportunity for natural attenuation of discharging $\mathrm{CHC}$ groundwater contaminants at the groundwater - surface water interface (GSI) and hyporheic zone therein. This is prior to their transfer at to the wider hydrosphere, biosphere and, due to their volatility, atmosphere.

The Environment Agency (2009) define: the hyporheic zone as being that portion of the fluvial sediments in which there is exchange of water from the stream into the riverbed sediments and then returning to the stream, within the timescales of days to months. Several processes influence $\mathrm{CHC}$ plume fate in the riverbed - hyporheic zone environment at the GSI (Bencala, 2000; Environment Agency, 2009). Although dilution due to surface-water mixing into discharging groundwater plumes within the hyporheic zone does not remove contaminant mass, it may reduce concentrations impacting surface waters (Conant et al., 2004; Hamonts et al., 2009). Sorption is often more significant than in the preceding aquifer as riverbed deposits are often rich in organic matter, leading to retarded transport and greater residence times (Smith and Lerner, 2008). Typically though, biodegradation is expected to provide the most significant attenuation process. This process requires appropriate electron donor and acceptor availability, the presence of an appropriate microbial community and increased residence time in the riverbed sediments (Hamonts et al., 2009; Kotik et al., 2013; Moser et al., 2003). Elucidation of the above processes influencing CHC plume fate must be underpinned by an understanding of flow regime in the GSI (Cardenas et al., 2007, 2008; Environment Agency, 2009).

Our study focuses upon field-scale variation in CHC natural attenuation occurring within the riverbed hyporheic zone due to the well-known anaerobic reductive dechlorination pathway (Maymo-Gatell et al., 1995; Vogel and McCarty, 1985; Vogel et al., 1987). Sequential dechlorination of TCE through cisdichloroethene (cDCE), vinyl chloride (VC) generating non-toxic ethene (and potentially ethane) (Bradley, 2000; Lorah et al., 2005) is studied. However, partial dechlorination may cause cDCE and VC to accumulate. This may be attributed to the limited availability or activity of specific dechlorinating bacteria such as Dehalococcoides, inadequate reducing conditions and insufficient electron donors (organic matter) or competing degradation processes (Bradley, 2000; Freedman and Gossett, 1989; Maymo-Gatell et al., 1995; Maymo-Gatell and Anguish, 1999). The lesser chlorinated hydrocarbons (LCHCs) may be susceptible to alternative anaerobic (Bradley et al., 1998) or aerobic (Abe et al., 2009) oxidation pathways. VC in particular may undergo aerobic oxidation, even at very low oxygen concentrations that may have been judged in error to be anaerobic (Gossett, 2010). Assessing the importance of mixing of aerobic surface water in the hyporheic zone (Ellis et al., 2007) may hence be important, but proving aerobic biodegradation of LCHCs at the field scale remains technically challenging (Abe et al., 2009; Cox et al., 2010). From a dechlorination perspective, hyporheic zone mixing of a CHC plume discharge with oxygenated surface water may be counterproductive to that reaction as anaerobic conditions may no longer prevail, at least for a period of time.

Frequent real-site observations of $\mathrm{CHC}$ groundwater plumes eventually discharging to surface water systems (McGuire et al., 2004), legislative drivers such as the European Community Water Framework Directive 
(CEC, 2000), and modelling studies requiring field data validation (Krause et al., 2014), each provide impetus to undertake detailed field-scale studies. CHC plume studies include: detailed evaluation of hydrogeological and biogeochemical controls on the Pine River, Canada (Conant et al., 2004; Abe et al., 2009); assessment of biodegradation potential on the Zenne River, Belgium including the use of advanced compound-specific isotope and microbiological tools (Hamonts et al., 2009, 2012; Kuhn et al., 2009); attenuation in lower flow, higher carbon, wetland environments within the US (Lorah et al., 2005); and, the assessment of plume discharge and loss to atmosphere from small receiving streams upstream of a main river receptor in the US (Chapman et al., 2007). The challenge of monitoring scales and heterogeneity in plume discharges are also prominent in most of the above studies as well as the UK studies of Weatherill et al. (2014) who examine the use of nested monitoring on the River Tern, and Ellis and Rivett (2007) who assess city-scale impacts on the River Tame.

Our study focuses in detail on a 50-m long reach set within the more sparsely monitored 7-km long reach of the Tame studied by Ellis and Rivett (2007). It exhibits several contrasting features relative to the cited studies. It involves a relatively complex end-of-pool - riffle - glide reach sequence. It is located within one of Europe's most urbanized headwater catchments. The setting is a high energy river system with a resultant riverbed that is mostly armoured containing a heterogeneous range of poorly-sorted sediments rich in pebbles and cobbles in-filled with finer sediments. These features are contrasting with the lower energy (often more meandering) river reaches generally described in the aforementioned literature studies that tend to involve riverbed sediments rich in sands (and sometimes gravels), clays and silts with more occasional peat deposits. Also in contrast to the above studies that typically present cross-river transect or shallow plan view data, we predominantly focus upon an in-river, near-bankside, monitoring transect oriented longitudinally along the reach. This is to provide a detailed measure of $\mathrm{CHC}$ attenuation variation along the monitored reach.

Our aim was to assess physico-chemical processes controlling field-scale variation in riverbed - hyporheic zone $\mathrm{CHC}$ dechlorination of a TCE groundwater plume discharging to an urban river reach. The 50-m long predominantly riffle - glide reach of the River Tame in Birmingham (UK) studied appears to be a higher energy river and heterogeneous riverbed environment compared to previously studied systems. The reach length studied of $50 \mathrm{~m}$ is similar to that of a small industrial site facility and variation within this scale is important for site problem holders to consider when designing what will be typically much sparser monitoring networks. The 50-m reach study usefully complements our previous studies on the River Tame concerning: interactions with the unconfined Birmingham aquifer reach studied over a $7 \mathrm{~km}$ long 'city scale (Ellis and Rivett, 2007; Shepherd et al., 2006; Rivett et al., 2011); examination of cross-river transects of plume discharges (Ellis and Rivett, 2007; Rivett et al., 2008); and, assessment of transient exchange processes (Cuthbert et al., 2010; Ellis et al., 2007; Roche et al., 2008).

\section{Methods}

\section{$2.1 \quad$ Field site and instrumentation}

The field study site is located on a 50-m long reach of the River Tame within the UK's second largest city, Birmingham. The Tame drains the greater West Midlands conurbation. Significant industrialization of the Tame headwaters catchment has occurred since the $19^{\text {th }}$ century. Within Birmingham, the Tame is typically $10 \mathrm{~m}$ wide and $0.2-2 \mathrm{~m}$ deep. River flow under low-flow conditions at the study site is around $150-200$ $\mathrm{Ml} / \mathrm{d}\left(1.7-2.3 \mathrm{~m}^{3} / \mathrm{s}\right.$ ) (based on the Environment Agency gauging site $0.5 \mathrm{~km}$ downstream). Around $45 \mathrm{Ml} / \mathrm{d}$ is due to an upstream sewage treatment works discharge to the Tame (Daily and Buss, 2014). Towards an order of magnitude increase in flow is possible under flood conditions on the Tame as the river efficiently 
drains the wider conurbation leading to a characteristically flashy urban hydrograph (Rivett et al., 2011; later figures). Previous larger scale studies have investigated groundwater impacts on Tame water quality over a 7-km reach through Birmingham where the underling Triassic sandstone aquifer naturally discharges to the Tame (Daily and Buss, 2014; Ellis and Rivett, 2007; Rivett et al., 2011; Shepherd et al., 2006). The aquifer contains widespread and persistent CHC contamination (Rivett et al., 1990a,b, 2005, 2012) as well as metals and other inorganic contaminants typically associated with urban aquifers (Ford et al., 1992; Ford and Tellam, 1994; Tellam, 2007). Now that plume interception by industrial groundwater abstractions has gradually declined with industrial recession, plumes are expected to be predominantly migrating towards the river Tame, the natural drainage point of the aquifer.

The study site was developed from a sparse cross-river monitoring transect installed by Ellis and Rivett (2007) that was found to be contaminated by a TCE plume that probably originates from industrial sites a little to the north of the river. The site is located on a thin (unproven thickness) of the Triassic sandstone very close to its boundary with the Carboniferous 'Coal Measures' (mudstones with sandstone units and occasional coal units). The study reach is shown in Fig. 1 alongside a plan of relevant monitoring installations made over the period 2005-12. The river is around $14 \mathrm{~m}$ wide with natural banks and bed and is surrounded along this reach by a thin strip of park land with urbanised land beyond comprising mixed light industrial and residential areas. The $50 \mathrm{~m}$ reach covers almost all of the TCE plume discharge. Piezometers located $25 \mathrm{~m}$ up and downstream of the reach showed non-detectable $(<0.5 \mu \mathrm{g} / \mathrm{L}$ or $0.0038 \mu \mathrm{mol} / \mathrm{L}) \mathrm{TCE}$ concentrations (areas immediately beyond the $50 \mathrm{~m}$ reach were less safe for access to constrain the plume boundaries). The river is shallow at $0.1 \mathrm{~m}$ depth near the southern bank but deepens to a channel $(0.5-1 \mathrm{~m}$ depth) near the north bank from which the TCE plume discharges. A pool - riffle - glide sequence exists with a large willow tree on the upstream section north bank providing a lower flow, silty riverbed deposit adjacent to that bank. 


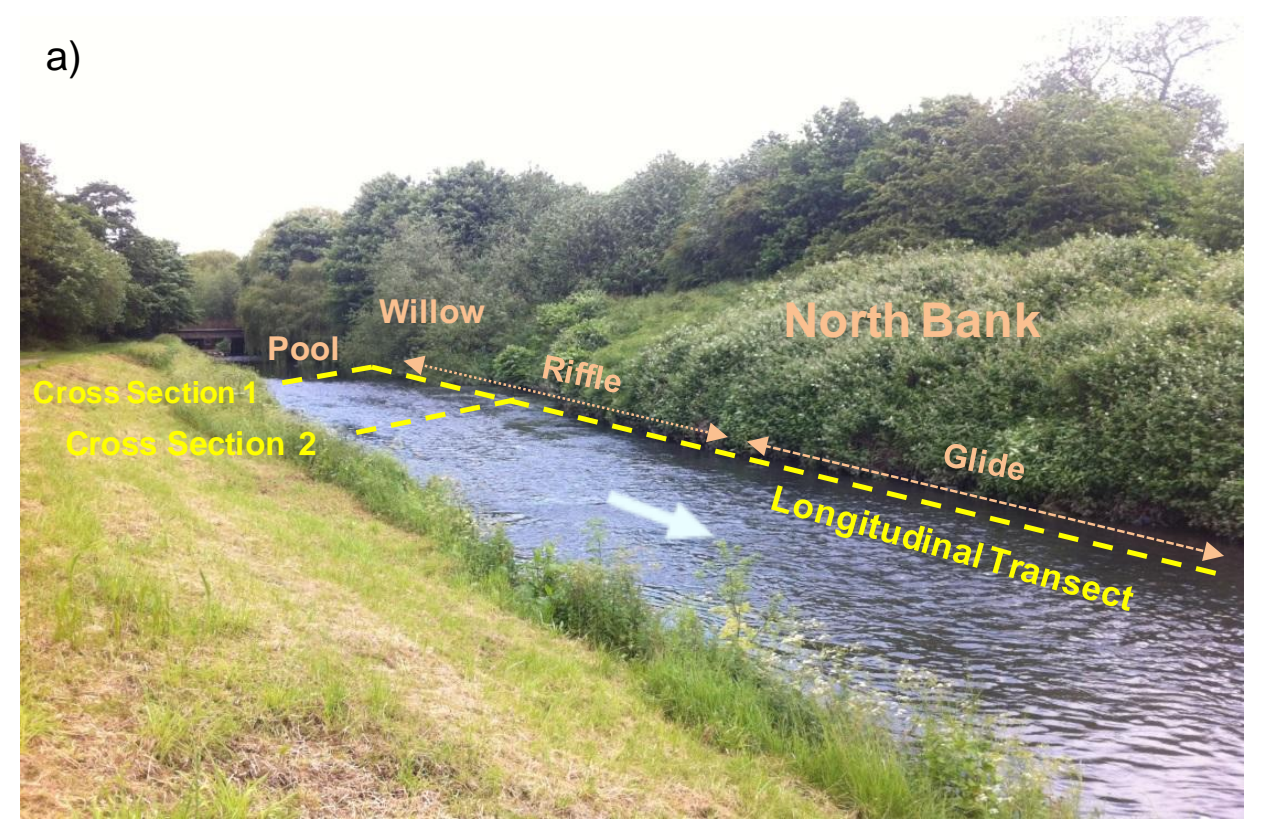

b)

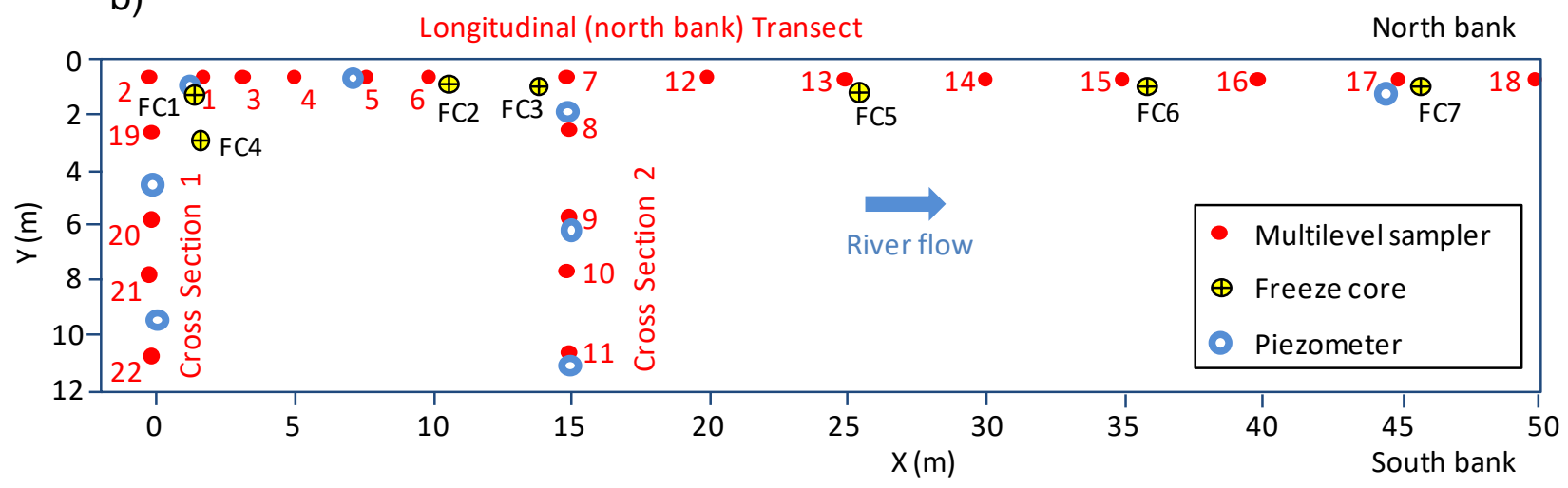

Fig. 1. a) Plate showing study reach; b) map of relevant study reach monitoring installations.

Our monitored reach begins at the tail end of the pool that pinches out near the willow into a riffle that becomes a more even glide at around 25 to $30 \mathrm{~m}$ into the reach (Fig. 1). Much of the reach river bed comprises a firm armoured gravel-pebble surface with porosity infilling by finer sediments resulting in a poorly sorted deposit confirmed by grab samples from the riverbed. The configuration of the study reach causes it to exhibit river-flow velocities that are higher than many parts of the Birmingham aquifer reach studied by Ellis and Rivett (2007).

Sediment characterisation of the shallow riverbed was undertaken over the $50 \mathrm{~m}$ reach with riverbed samples to $0.1-0.15 \mathrm{~m}$ depth taken at $2 \mathrm{~m}$ intervals along the river length and at $1 \mathrm{~m}$ intervals across the river. It was apparent from our periodic observations spread over the period 2005-12 that there was an occurrence of temporary sand lenses associated with macrophytes. The lenses accumulated during the summer as the growing vegetation filtered and deposited sediment suspended in the river water. We have occasionally mapped these features in different years within the study reach and retrieved sediment samples for laboratory characterisation.

Conventional sieve analysis of sediment and soil samples was undertaken and hydraulic conductivity $(K)$ estimated from grain-size distributions. Determining the hydraulic conductivity of such poorly sorted deposits is not trivial. Our grain-size $K$ estimates were based on samples sieved to remove clasts larger than 
$4 \mathrm{~mm}$, these being interpreted to make up the permeable pathways between the effectively impermeable pebbles and cobbles. Several methods were used to determine $K$ from grain size distribution curve data with preferred estimates based on the ranges of method applicability indicated in Song et al. (2009).

To characterize the deeper sediments (down to $\sim 0.5-0.7 \mathrm{~m}$ below riverbed), seven freeze cores were collected from along the north bank. A hollow metal tube was hammered to the desired depth, and liquid nitrogen was poured into the tube via a funnel in small amounts at a time. Allowing a few minutes to freeze, the metal tube was attached to a winch and lifted out of the riverbed using a tripod support. This procedure, adopting relevant safety protocols, allowed the local structure of the riverbed to be seen. In contrast, more conventional coring approaches performed poorly due to the very large grain sizes often encountered. The freeze coring technique, although used in hyporehic zone or lake bed research in other contexts (Pugsley and Hynes, 1983), appears under used in contaminated groundwater discharge studies. Grab samples of the sand lenses and intermediate depth drive tube cores were also taken for organic matter measurements.

Piezometers and multilevel (ML) samplers were constructed of flexible HDPE or Teflon ${ }^{\circledR}$ tubing installed using manual drive-tube and fence-post hammer methods that involved no sediment removal (Rivett et al., 2008). Hydraulic heads were monitored in 9 piezometers, at depths below riverbed ranging from 0.4 to $1.0 \mathrm{~m}$. The piezometers were constructed with $10 \mathrm{~mm}$ diameter HDPE tubing, with $10 \mathrm{~cm}$ intakes manufactured by drilling small holes into the tubing, the latter being covered by $100 \mu \mathrm{m}$ nylon mesh before installation (Rivett et al., 2008). Hydraulic conductivity estimates were obtained from the piezometers using falling head tests. For water quality sampling, 22 multilevel samplers each containing 5 sampling ports spaced at $10 \mathrm{~cm}$ vertical intervals were installed. These samplers were distributed within one 'Longitudinal Transect' located in the river channel about $1 \mathrm{~m}$ from the north bank and two cross-river transects, perpendicular to the bank, referred to as 'Cross Section 1' and 'Cross Section 2' (Fig. 1). The samplers were constructed using $3.2 \mathrm{~mm}$ OD $1.6 \mathrm{~mm}$ ID Teflon ${ }^{\circledR}$ sample tubing attached to a central steel support rod of sufficient strength to overcome the challenging site geological conditions (Rivett et al., 2008).

\subsection{Sampling and analysis}

Water samples for CHC analysis were collected directly from the multilevel sampler Teflon ${ }^{\circledR}$ sample tubing that were temporally inserted into a stainless steel sample head device positioned on an inert Viton O-ring $40 \mathrm{~mL}$ glass vial with the assembly completely sealed in line prior to a peristaltic pump. The configuration minimized losses by volatilization and sorption (Einarson, 2001). Purge volumes were limited to a few $\mathrm{mL}$ (possible because of the narrowness of the Teflon ${ }^{\circledR}$ sample tubing) with a total sample water volume removal of a few hundred $\mathrm{mL}$, thus allowing retention of reliable vertical water quality profiles for the $10 \mathrm{~cm}$ increment ports. Field measurements of dissolved oxygen, redox potential, $\mathrm{pH}$, temperature, and electrical conductivity were made using hand-held Hanna ${ }^{\circledR}$ instrument probes and a set of Waterra ${ }^{\circledR}$ flow-through cells. Redox potential and $\mathrm{pH}$ were measured using a Hanna HI 9025 meter and probes.

CHC concentrations were monitored in 8 sampling events between August 2005 and September 2007 and a later event in August 2011. Water samples were analyzed using conventional GC-MS headspace analysis using an Agilent Technologies Model 6890 series gas chromatograph equipped with a Gerstel MPS2 autosampler and Agilent Technologies 5973 mass spectrometer. Samples were analyzed within 1 to 3 days of collection and stored at $4^{\circ} \mathrm{C}$ prior to analysis. Detection limits were $<0.5 \mu \mathrm{g} / \mathrm{L}$ for targeted CHCs (maximum $0.008 \mu \mathrm{mol} / \mathrm{L}$ ). Ethene, ethane and methane were analyzed in one sampling campaign (September 2007) using GC-FID analysis. Water samples were collected similarly for inorganic determinants, and analyzed using a Dionex ICS-90 ion chromatograph.

Fraction of organic carbon $\left(f_{o c}\right)$ was determined on 31 samples, 22 collected at different depths in three shallow soil cores with the remainder being sediment grab samples. Total organic carbon content (TOC) was 
measured using the Solid Sample Module of the Shimadzu Total Organic Carbon Analyser (SSM-5000A) and determined from difference of total carbon and inorganic carbon. Dissolved organic carbon (DOC) of water samples was also measured on this instrument.

\subsection{Data analysis methods}

\subsubsection{Surface-water mixing - estimation via chloride data}

Effluent piped discharges to the Tame from upstream wastewater treatment plants and winter road salt applications cause surface water chloride concentrations $(c .180 \mathrm{mg} / \mathrm{L})$ to be higher than the groundwater concentrations (typically $<50 \mathrm{mg} / \mathrm{L}$ ). This permitted chloride concentrations to be used as a tracer of surface water / groundwater mixing in the hyporheic zone (Rivett et al., 2011). The dechlorination of CHC concentration maximum values in the range of $1 \mathrm{mg} / \mathrm{L}(0.016 \mu \mathrm{mol} / \mathrm{L})$ would not yield sufficient chloride to confound this application. Fractions of surface water $\left(f_{S W}\right)$ in the riverbed deposits were estimated using:

$f_{S W}=\frac{C_{i}-C_{G W}}{C_{S W}-C_{G W}}$

where: $C_{i}$ is the ML sample chloride concentration; $C_{G W}$ is the average chloride concentration in the groundwater; and $C_{S W}$ is the surface water chloride concentration. Values of $C_{S W}$ were adjusted to reflect surface water variations in time (Rivett et al., 2011).

\subsubsection{Natural attenuation capacity}

The capacity of a riverbed - hyporheic zone to cause attenuation, its 'natural attenuation capacity' (NAC), is of key interest and may be defined as the reduction in contaminant flux achieved through natural attenuation processes during contaminant passage through the riverbed. In practice, it is recognized NAC can be variously defined or approximated to allow for the constraints of data availability and site conditions. Under the simplification of an assumed constant water flow, flux reduction may be replaced by concentration reduction that may be used to provide a more convenient, albeit a more approximate indicator of NAC. A key consideration, however, near the riverbed interface is that concentrations may be reduced by surface water mixing and hence lead to an over estimation of the reactive NAC. Therefore, it is important to recognize this dilution process and incorporate it as a process within the NAC definition assumed.

One possible way to account for the dilution process is to calculate the ratio of biodegradation daughter product to parent $\mathrm{CHC}$ concentration. This provides a convenient indicator of spatial variation in dechlorination activity that is not, unlike absolute concentration, affected by dilution.

We further propose Chlorine Number reduction (absolute or percentage) achieved during passage through the interface zone as a convenient indicator of NAC. 'Chlorine number' $(\mathrm{CN})$ is calculated as the molar average chlorine number of PCE, TCE, cDCE, VC and ethene detected in a sample (Weaver et al., 1997) (eq. 2)

$C N=\frac{\sum w_{i} C_{i}}{\sum C_{i}}$

where: $w_{i}$ is the number of chlorine atoms in molecule $i$ and $C_{i}$ is the molar concentration of each ethene species. Hence if the sample was comprised of just TCE, the $\mathrm{CN}$ would be 3 , if a 50/50 molar concentration of $\mathrm{CDCE}$ and $\mathrm{VC}$ the $\mathrm{CN}$ would be 1.5, and if it has fully degraded to ethene alone, the $\mathrm{CN}$ would be zero. 
An important advantage of using a $\mathrm{CN}$ approach is that it is not significantly influenced by riverbed invading surface-water dilution (effectively zero $\mathrm{CHC}$ concentration) and usefully provides an indicator of the progression of the stepwise dechlorination process as a whole. Although we are aware of the use of chlorine number based metrics by practitioners in, for example, the assessment of bioremediation and monitored natural attenuation at sites (Weaver et al., 1997), its use appears not to be common in the published CHC dechlorination literature.

\section{Results}

\subsection{Physical characterisation}

\subsubsection{Geological observations}

The spatial distribution of the predominant grain-size categories for very shallow riverbed sediments are shown in plan view in Fig. 2. The shallow riverbed deposits were predominantly conglomeratic, with pebble or cobble-sized clasts and a sandy matrix typically of about $30-40 \%$. The riverbed surface was predominantly tightly packed giving a firm armoured interface. More fine-grained deposits of sand, silt or clay only became locally dominant towards some of the bank sides with some deposits on the northern bank possibly associated with bank collapse. Greatest accumulations of fine-grained deposits were towards the upstream north bank associated with a low flow zone around and downstream of the large bank-side willow (Fig. 1). Sediments in this area contained $>90 \%$ of sediments classified as fine-grained and were soft under foot with occasional gas released smelling of hydrogen sulphide demonstrating local reducing conditions.

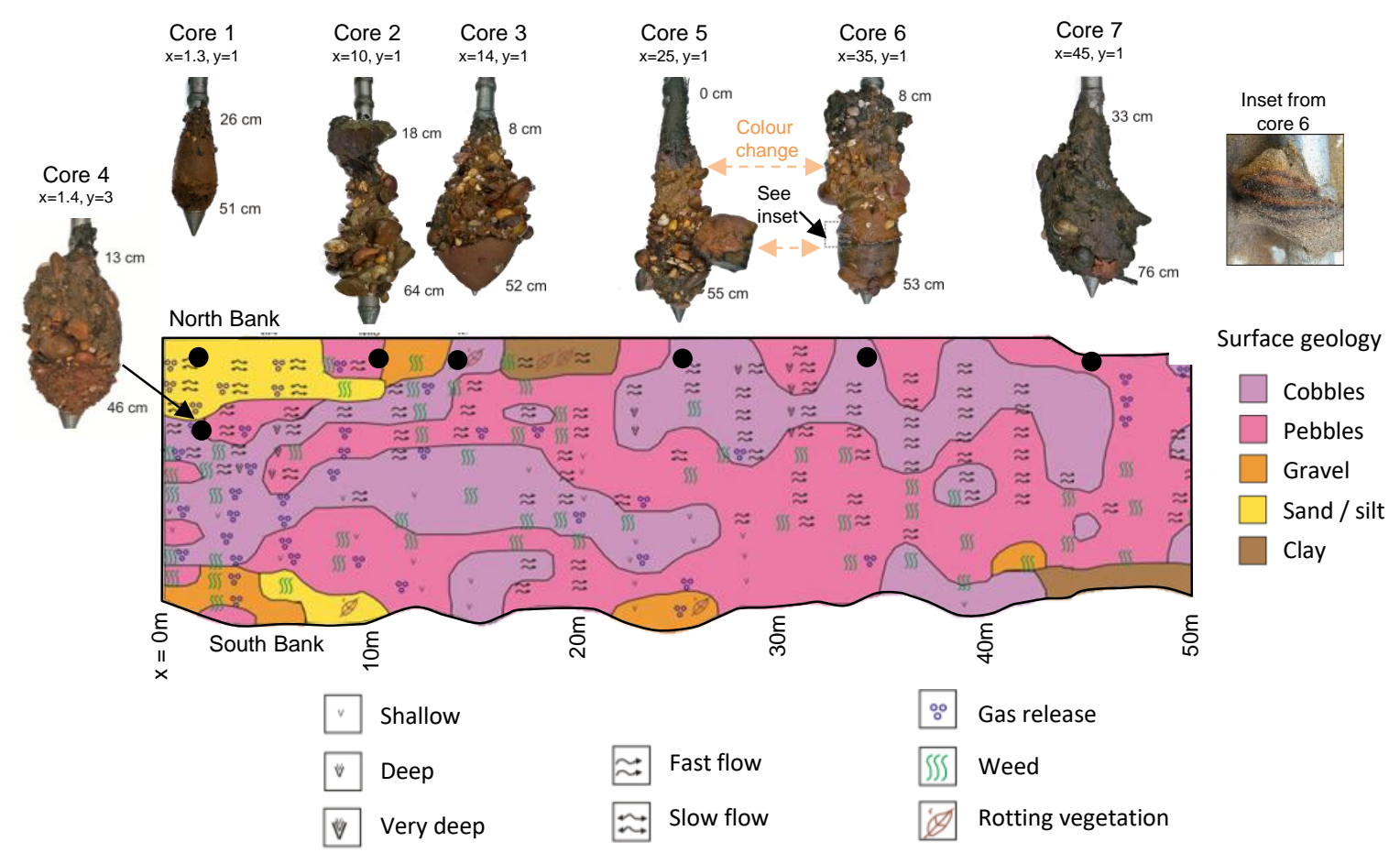

Fig. 2. Shallow riverbed sediment map (May 2006) depicting spatial distributions of the predominant grain size categories and photographs of riverbed freeze cores retrieved from close to the line of the north bank Longitudinal Transect (centered at their relevant $x$ distance along the transect) and an additional core, Core 4 located $3 \mathrm{~m}$ from the bank. 
The shallow sediments shown in Fig. 2 were mapped in late spring 2006 ahead of the main growth of macrophytes (predominantly Ranunculus) that often influenced bed-sediment accumulation. Our ad-hoc periodic observations spread over 2005-12 revealed macrophytes to be present annually though growth varied significantly. Although occasionally macrophyte occurrence was negligible (for example, the summer of 2011), most years witnessed the majority of growth in the mid to upper parts of the reach. Occurrence was more significant towards the north bank (perhaps due to greater sunlight). Rooted zones may act as an organic carbon donor, provide CHC phyto-degradation opportunity and modify flows. An additional macrophyte influence was the seasonal build-up of significant lenses (or hummocks) of predominantly finemedium grained sandy sediment (up to c. $0.4 \mathrm{~m}$ deep and c. $5 \mathrm{~m} \mathrm{long}$ ) over the armoured pebble-cobblesandy surface. Sand lenses built up beneath trailing macrophytes due to reduced river flow rates and or suspended sediment filtering (cf. Sanders et al., 2007). Centimetre or so thicknesses of dark, presumably reduced, sediment occurred at the lens contact with the river. Also, black, low-density clasts, presumably composed of carbon, were often observed in eddies in the lee of the frequently eroded tails of the sand lenses.

Flood events during autumn / winter were observed to uproot entire (decaying) macrophyte stands and wash out hummock sand lenses. However, some macrophyte stands persisted from year to year and it is possible that some sand lenses are preserved within the riverbed sediment profile. Fig. 2 shows the distribution of emergent vegetation prior to the seasonal macrophyte growth and accumulation of sand lenses. Our field monitoring multilevel sampler installations did not specifically target the influence of macrophytes and associated sediment accumulations on flow or natural attenuation (other than some preliminary work), but this would be worthy of future research. The transient nature of the urban riverbed studied is, however, clear.

Freeze coring was instructive in showing the complex heterogeneous structure of the riverbed as well as indicating areas of potentially reducing or oxidizing conditions (inferred from observations of sediment coloration) (Fig. 2). Very poorly sorted layers were generally prominent. Typically large (to occasionally massive) cobbles, rock fragments and pebbles (pebbles $=4-64 \mathrm{~mm}$; cobbles $=64-256 \mathrm{~mm}$; boulders $=$ $256-4096 \mathrm{~mm}$ ) were present with an interstitial space in-filled with a range of poorly sorted finer materials ranging from medium to coarse sands through to fine sands and silts. The bank side cores from between $x=$ $10 \mathrm{~m}$ and $x=35 \mathrm{~m}$, as well as Core 4 located further from the bank at $x=1 \mathrm{~m}$, illustrate the continuity and thickness of the poorly sorted sediments throughout much of the reach. These observations accord with the surface mapping (Fig. 2). Tortuous flow is expected within the finer-grained material of such poorly sorted sediments in order to circumvent impermeable pebbles and cobbles present. Within the downstream glide area (Core 7, $x=45 \mathrm{~m}$ ), finer sediments become more prevalent. Occasionally massive angular rock material of unknown origin was recovered (Cores 2 and 5). When non-porous, these may be a significant barrier to flow. Direct evidence of modern riverbed accumulation was occasionally afforded; for example, through the observation of barbed wire at $0.3 \mathrm{~m}$ depth (Core 2).

Comparatively well-sorted fine- to medium-grained sand layers were observed both above and below the poorly sorted pebble/cobble-rich unit. Red/orange sediments of a more oxidised appearance were observed at depth in several of the core. These varied from clean sands in Cores 3 and 6 to more poorly sorted sands in Core 4 that contained cobbles and low permeability fine sands and red clays. Sediments of a dark olive / grey /black appearance, indicative of potentially reducing conditions, consisted of fine-grained silts, sands and even occasional clay/mud units. They appeared significant throughout Core 7 in the downstream glide. Localised organic matter was obvious on inspection with discrete black bands and other sharp colour change interfaces evident that were suggestive of redox fronts. This is illustrated by the Fig. 2 inset for Core 6 and also the coloration of the large porous rock fragment in Core 5. These cores, although sampling contrasting grain-size units and separated by $10 \mathrm{~m}$, do in fact show very similar changes in colouration with depth: a near-surface grey zone suggestive of reducing conditions; an intermediate red/orange more oxidised layer; a 
sharp transition (inset Fig. 2) into dark, more reduced sediment at depth. Core 5 at $25 \mathrm{~m}$ (Fig. 3) exhibits a moderate thickness of well sorted sandy sediment near surface with evidence of near surface vegetation. Its apparent contradiction with the mapped cobbles at this locality is attributed to the different timings of these datasets and the probable influence of macrophyte related sediment deposition since the mapping several years previously. Significant fine sediment content was observed near surface under the willow tree pool area which had been shown by conventional shallow coring to be of silty, organic-rich, deposits.

\subsubsection{Organic matter}

Riverbed sediment fraction of organic carbon $\left(f_{o c}\right)$ (that may provide sorption sites or might provide organic matter that may serve as an electron donor) was observed to vary from $<1 \%$ to more than $6 \%$ in depth profiles from three shallow (not freeze) cores taken from specific multilevel installation sites within the Longitudinal Transect (for $x=0$ to $10 \mathrm{~m}$ ) as well as several shallow sediment grab samples (Fig. 3). Maximum values in ML1 and ML3 occurred near to the riverbed interface and declined with depth to around $1-2 \%$ at $0.2-0.25 \mathrm{~m}$ depth. Some localised high values were attributed to discrete layers of organic-rich material (Fig. 3). The high $f_{o c}$ values in the shallow horizons of the above core were attributed to the influence of the pool tail end - willow tree locality where silty - organic detritus rich material accumulates. The profile further downstream at $x=10 \mathrm{~m}$ (Fig. 3), beyond the influence of the low river flow - willow tree area, exhibited a quite uniform and low $f_{o c}$ with depth. Freeze core data indicate it to correspond to an area containing poorly sorted sediments where the river surface was armoured $\left(f_{o c}\right.$ data were based on samples of the finer grained interstitial materials). The shallow grab sample $f_{o c}$ values shown in Fig. 3 are consistent with the extremes in the vertical profiles found in the shallow horizons.

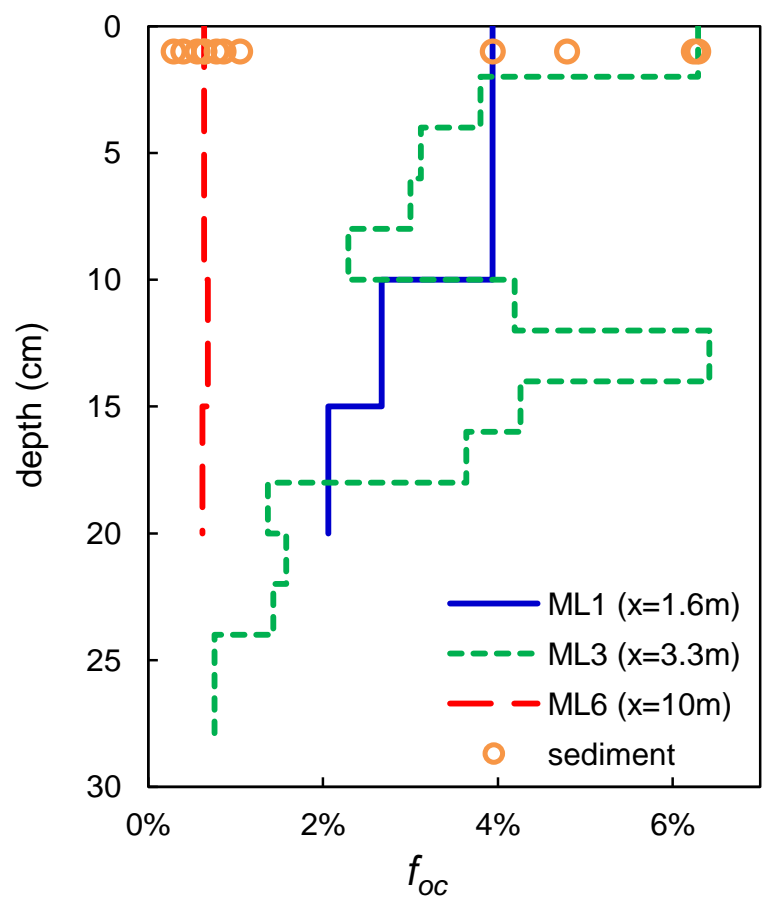

Fig. 3. Fraction of organic carbon $\left(f_{o c}\right)$ in sediment grab samples and in soil samples from shallow core close to the multilevel wells.

Additional to the resident geological or on-going suspended sediment deposition of sedimentary organic matter, organic matter (carbon) may enter the hyporheic zone of the riverbed through surface-water invasion (mixing). This may be in the form of dissolved or particulate organic matter (DOM or POM). Our 
measurement of dissolved organic carbon DOC (dissolved organic carbon) on River Tame samples indicate an average DOC value of around $7 \mathrm{mg} / \mathrm{L}$ with the range in values typically from around 4 to $10 \mathrm{mg} / \mathrm{L}$.

\subsubsection{Potentiometric measurements and hydraulic conductivity}

The groundwater-surface water interactive flow regime was expected to be relatively complex given the presence of a pool - riffle - glide sequence (Fig. 1); the main channel close to the north bank; the moderately variable riverbed relief elsewhere; the transient effects of the vegetation, and the heterogeneous permeability distribution. Vertical hydraulic gradients across the riverbed deposits varied spatially but, with the exception of one measurement (near the south bank, $x=15 \mathrm{~m}$ ), were directed upward (Fig 4). Short term gradient reversals during rainfall events were, however, expected based on transducer data from piezometer arrays a little further downstream on the Tame outside the present study reach (Cuthbert et al., 2010). Head gradients at our site (biased to low river-stage conditions when most monitoring was undertaken and access safe) were typically $c .0 .05-0.2$ with lowest gradients towards the south bank and mid stream and higher gradients towards the north bank. Steeper gradients were found along the upstream north bank, near Cross Sections 1 and 2 in particular. These are attributed to the presence of the low permeability silts associated with the upstream willow tree area where flows are slowed by the pool feature, silts from a nearby pipe outfall (detailed later) and bankside collapse and deposition from the slower flow in this part of the channel (Fig. 2). The sediments in the upper parts of Core 4 (a little further from the north bank within Cross Section 1) were also predominantly fine grained (Fig. 2). These observations suggest there is some continuity of these less permeable near surface units that may inhibit flows. Contoured heads for the Longitudinal Transect (Fig. 4) provided some evidence of a component of along river through flow (around 15 to $40 \mathrm{~m}$ ) in a downstream direction within the riverbed deposits and this is consistent with the up-gradient pool - riffle - glide reach configuration. The variable topography of the riverbed, particularly in the vicinity of the channel near the north bank, may be expected to lead to complex local flows at the GSI that would require significant head data to resolve.

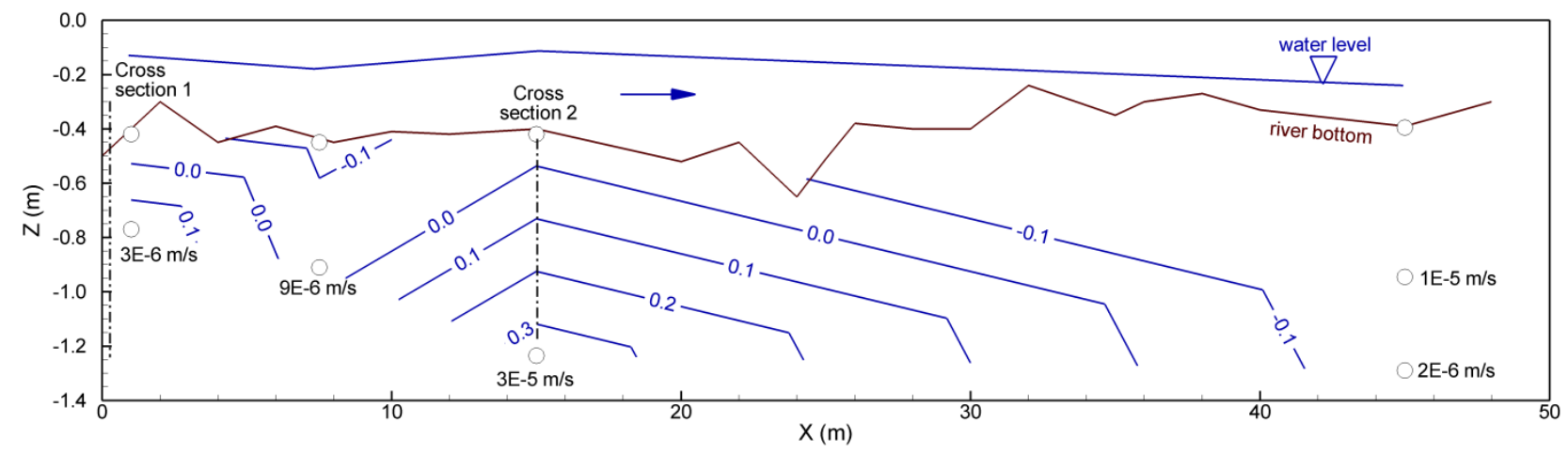

Fig. 4. Hydraulic head distribution (relative to an arbitrary site datum) for the north bank Longitudinal Transect (July 2006). Open circles indicate location of piezometers, and slug test hydraulic conductivity values $(\mathrm{m} / \mathrm{s})$ are also indicated.

\subsubsection{Hydraulic conductivity}

Samples tested for hydraulic conductivity were typically poorly sorted with upper $K$ estimates based on grain-size distributions of $0.6-0.9 \mathrm{~m} / \mathrm{d}$ being found for lower fine contents (4\%) sandy deposits. Values of 
$0.7-1 \mathrm{~m} / \mathrm{d}$ were found for the much more homogeneous sand-lens accumulations associated with macrophytes. Similar $K$ estimates of $0.3-0.5 \mathrm{~m} / \mathrm{d}$ were associated with samples containing moderate levels of fines (c. 30\%). Values of $<0.2 \mathrm{~m} / \mathrm{d}$ were typically associated with samples with greater fines contents: for example, values of $0.02-0.03 \mathrm{~m} / \mathrm{d}$ were estimated for samples with $c .60 \%$ fines. These estimates reasonably compare with reach slug test values ranging from 0.3 to $3.5 \mathrm{~m} / \mathrm{d}$ with lower estimates from core localities with finer-grained deposits more evident (Cores 1, 4 and 7 in Fig. 2; Fig. 4).

Our values reasonably compare with the wider 7-km reach study of Ellis and Rivett (2007) who report riverbed slug test $(\mathrm{n}=44)$ arithmetic mean, median and geometric $K$ means of $3.13,1.34$ and $1.26 \mathrm{~m} / \mathrm{d}$ respectively, with a range of $0.08-23 \mathrm{~m} / \mathrm{d}$. Our failure to observe high-end values $(K \sim 10-25 \mathrm{~m} / \mathrm{d})$ is attributed to the absence of well sorted 'clean' gravels / pebbles at our site. In summary, a reasonable site $K$ estimate for all but the finer-grained deposits would be in the range $0.1-1 \mathrm{~m} / \mathrm{d}$. For the finer grained sediments with increased silts and clays, $K$ values closer to $0.01 \mathrm{~m} / \mathrm{d}$ (or even lower when very silt/clay rich and or units are continuous) would be appropriate. Although the site contains a very wide range of sediment sizes, the poor sorting of sediments tends to restrict the range of observed $K$ values with a lack of high values apparent. Within poorly sorted deposits, the presence of larger grain sizes, such as pebbles and cobbles, will act to block flow and reduce the overall $K$ of these deposits.

\subsection{Hydrochemistry}

\subsubsection{Flow assessment using surface-water chloride tracer data}

Understanding of the flow regime critically underpins assessment of contaminant fate. Contrasting estimates of the fraction of surface water present in the riverbed using chloride concentration data are shown in Fig. 5 for the Longitudinal Transect. Estimates are illustrated under contrasting hydrological conditions as indicated by the river stage data insets. Although the river stage was relatively high during and before monitoring over the winter - early spring (Fig. 5a), sampling was conducted on the falling limb of the river hydrograph under conditions of surrounding elevated groundwater levels due to proceeding winter - early spring recharge leading to strong groundwater gradients towards the river. Fig. 5a indicates a predominantly groundwaterdischarge condition with a very limited hyporheic zone at $x=12-32 \mathrm{~m}$ where surface water invasion was to depths of around $0.1-0.25 \mathrm{~m}$ in March 2007 (Fig. 5). Over the c. $12-32 \mathrm{~m}$ interval, a combination of increased riverbed $K$, different river morphology and different riverbed topography may explain the surface water invasion observed. Low chloride in the Longitudinal Transect at $x>32 \mathrm{~m}$ suggests that surface-water penetration was very limited (if any) and that this glide part of the reach was subject to simple groundwater discharge under fairly low hydraulic gradients (Fig. 4) and no hyporheic zone present. 


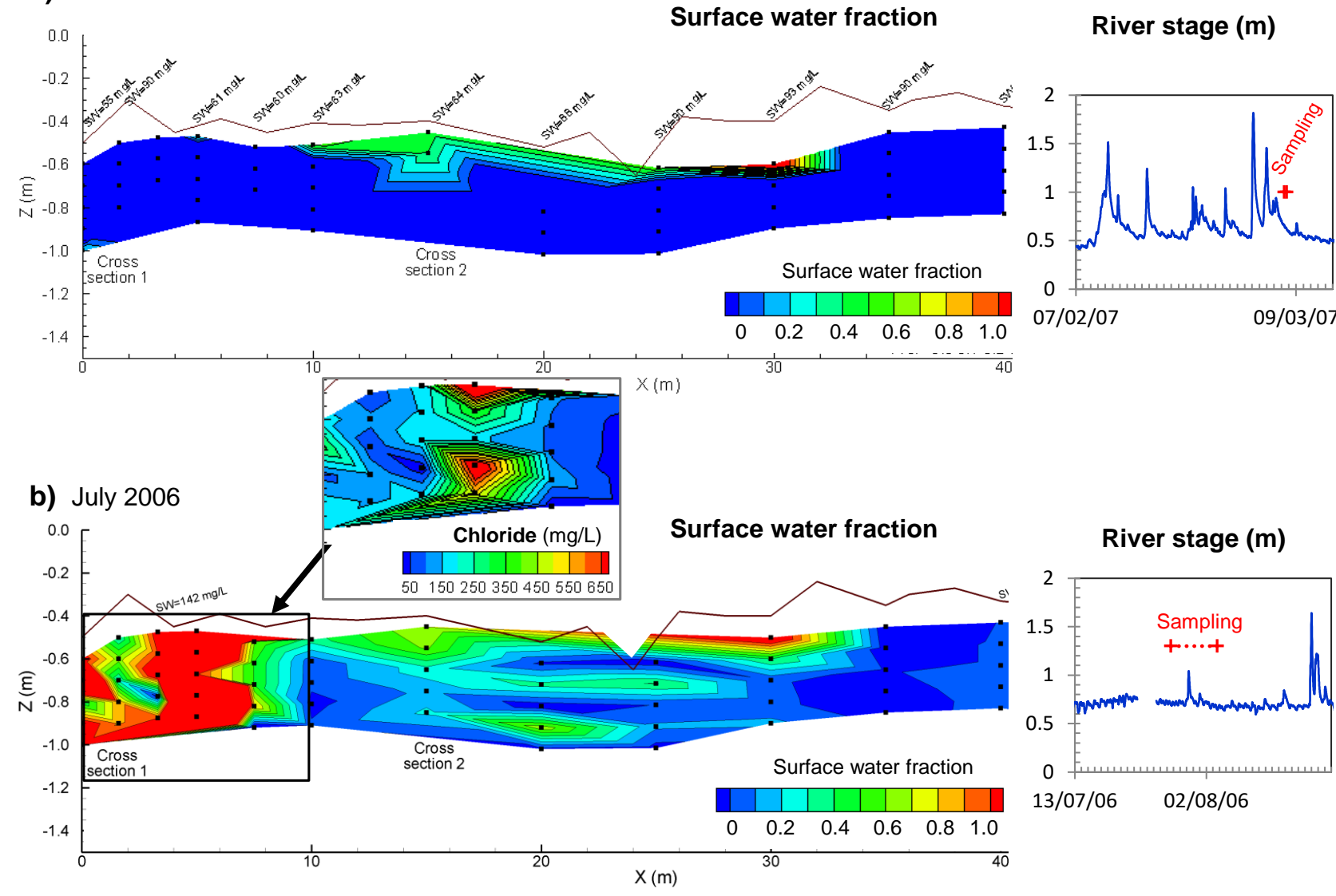

Fig. 5. Fraction of surface water mixing into the riverbed estimated from chloride concentration data for the north bank Longitudinal Transect and accompanying river stage hydrographs for a) March 2007 and b) July 2006 (incl. chloride data inset). Measurements of chloride in surface water are also indicated (SW).

Fig. 5b shows a more complex picture. Invasion of the surface water still occurs in the $x 12-32 \mathrm{~m}$ reach section, but to greater depth. This is attributed to the precipitation events that caused the $0.4 \mathrm{~m}$ river-stage increase and a smaller following peak during the mid to later parts of the sampling period (Fig. 5b hydrograph): these are assumed to have caused transient flow reversals that established temporary influent conditions. As the preceeding summer period had been dry, the surrounding water table level was unlikely to be substantially influenced by this discrete precipitation event and hence the potential for flow reversals and increased gradients away from the river during the event is increased.

Chloride concentrations (Fig. 5b inset) over the $x=0-8 \mathrm{~m}$ interval were extremely high and must relate to a local temporary point source influence as chloride concentrations returned to background levels (similar to Fig. 5a) within days. The most likely source of this contamination is a surface-water outfall pipe located on the north bank at this locality; this pipe discharges road runoff from a mainly residential containing some light industry / commercial facilities, but shares a trench with a foul sewer from which it may occasionally receive overflow. It is possible that there had been pipe discharge seepage to the near-bankside sediments and that the stage increase observed in Fig. 5b, under otherwise low-flow conditions drove this contaminated water deeper into the riverbed. Regardless of the explanation, the chloride data indicate that a complex and dynamic flow environment occurs in this upper reach and that surface-water mixing predictions using 
chloride around this part of the reach (and perhaps locally downstream) may be compromised at times. It is conceivable that a component of the $\mathrm{CHC}$ contamination observed in our study may relate to any unauthorised $\mathrm{CHC}$ presence in the aforementioned pipe discharge since peak observed CHC concentrations were found in the vicinity of the discharge. The temporal persistence of the CHC plume observed and its breadth of entry along the reach (later Figure 7), however, suggests that the pipe outlet itself is not the main CHC source, if a source at all.

\subsubsection{Redox and electron acceptor conditions}

The Longitudinal Transect redox potential data exhibited moderate to strongly reducing conditions $\left(E_{H}\right.$ below $-50 \mathrm{mV}$ ) in the upstream reach to around $x 30 \mathrm{~m}$ (Fig. 6a). The mean pH value was 7.2 with a standard deviation of 0.5 and minimum of 6.5. Most reducing conditions were found in the shallowest horizons over the $x=0-20 \mathrm{~m}$ interval. DO (dissolved oxygen) data, available only from the $x=5-30 \mathrm{~m}$ interval, confirm predominantly anaerobic to low oxic conditions over this interval (Fig. 6a) with $74 \%$ of samples below the detection limit of $c .<0.2 \mathrm{mg} / \mathrm{L} \mathrm{DO}, 20 \%$ at $>0.2-1 \mathrm{mg} / \mathrm{L}$ and $6 \%$ at $1-3 \mathrm{mg} / \mathrm{L}$. Transition to the more oxic, increased $E_{H}$, water occurred at around $x=25-30 \mathrm{~m}$ and maintained downstream of this interval.
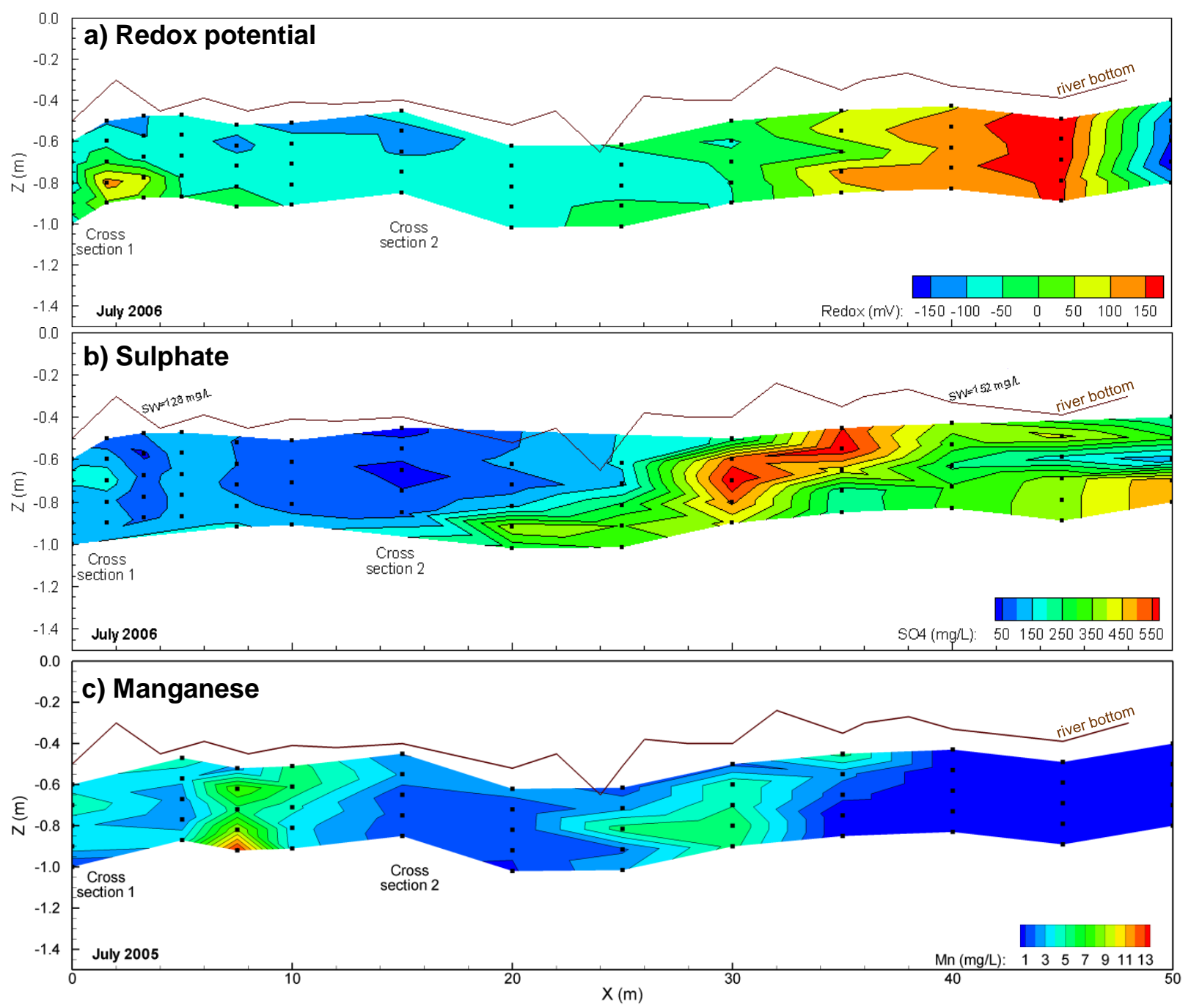
Fig. 6. North bank Longitudinal Transect: a) redox potential, b) sulphate, c) manganese. SW indicates concentrations measured in surface water.

The reducing conditions indicated by the redox potential data are broadly consistent with the manganese concentrations (Fig. 6c). Greatest manganese concentrations $(6-13 \mathrm{mg} / \mathrm{L})$ occurred at $x=8-10 \mathrm{~m}$ (ML 5 and ML6) close to the occurrence of the lowest redox potentials. Manganese concentrations elsewhere across the $x=0-30 \mathrm{~m}$ interval were generally at $1-5 \mathrm{mg} / \mathrm{L}$ and accorded with the more moderate reducing conditions. Manganese was below detection limit $(<0.25 \mathrm{mg} / \mathrm{L})$ downstream of $x=35-40 \mathrm{~m}$ and this is consistent with the transition to oxic conditions observed in this part of the reach. Iron concentrations were less informative as most concentrations were in and around the (high) detection limit of $\sim 0.25 \mathrm{mg} / \mathrm{L}$ with occasionally higher values.

Sulphate was relatively low $(<150 \mathrm{mg} / \mathrm{L})$ in the upstream part of the transect, but displayed very elevated concentrations up to $800 \mathrm{mg} / \mathrm{L}$ within the downstream $(x>20 \mathrm{~m})$ riffle-to-glide part of the reach (Fig. $6 \mathrm{~b}$ ). Elevated concentrations are ascribed to a discharging sulphate plume from a suspected local industrial source. The lower sulphate concentrations in the more upstream parts of the reach are consistent with the greater evidence for sulphate-reducing conditions present in that part of the reach, but may also in part arise from lower concentrations at the plume periphery.

Methane concentrations were highest, up to $1050 \mu \mathrm{g} / \mathrm{L}$, at $0.1 \mathrm{~m}$ below the riverbed at $x=2-4 \mathrm{~m}$ and were attributed to the presence of organic matter within the silty deposits. Although methanogenesis occurrence indicates conditions were sufficiently reducing for dechlorination, rates may be negatively influenced by methanogenic activity because methanogens compete with the dechlorinating bacteria for available hydrogen (Maymo-Gatell, et al., 1995; Yang and McCarty, 1998; Yang and McCarty, 2000).

Observations of gas release from the riverbed shown in Fig. 2 were most prevalent in the upstream part of the reach occurring fully across river over the $x=0-10 \mathrm{~m}$ interval near pool - upstream riffle area. Gas release over the $x=10-25 \mathrm{~m}$ interval trended diagonally cross stream from the north bank to the south bank, but was largely unapparent in the glide reach further downstream. Gas observations typically coincided with areas of silt, vegetation or rotting vegetation within the reach (Fig. 2). Olfactory observations of hydrogen sulphide were common in the main areas of gas release under low-flow river conditions providing evidence of sulphate-reducing conditions. Sulphide concentrations in water samples were below or just above detection in the range $>0.01-0.05 \mathrm{mg} / \mathrm{L}$; it is inferred these trace levels are indicative of sulphate reduction activity with iron (and possibly manganese) sulphide precipitation. Sulphide detections were most common within the near-surface riverbed water samples over the $0-25 \mathrm{~m}$ interval consistent with gas observations. Trace dissolved sulphide was more increasingly detected over the $0.3-0.5 \mathrm{~m}$ depth interval further downstream in the $x=30-50 \mathrm{~m}$ riffle section and was consistent with the increasing thickness of dark-coloured, more reduced appearing, sediments in the downstream sequence of Core 5, 6 and 7 (Fig. 2).

\subsection{CHC contamination}

\subsubsection{Spatial plume data}

Contrasting examples of TCE, CDCE and VC concentration distributions plumes observed on different dates are shown in Fig. 7 for the Longitudinal Transect. Due to the lack of upgradient aquifer data, plume origins are speculative, but are likely to be related to industrial areas to the north. In the upstream riffle and 
downstream glide parts of the reach there are high concentrations of total CHCs and TCE, but at around $\mathrm{x}=$ $30 \mathrm{~m}$, very low concentrations of both are observed. It cannot be determined if the observed plume discharges originate from single or multiple sources, became split due to geological heterogeneities, or have undergone varying degrees of attenuation during aquifer transport. It is conceivable there is a common source area of TCE and TCA (1,1,1-trichloroethane) for the coincident parts of those plumes in that the latter was used in place of TCE (from around $1970-2000$ in the UK). Observed much lower (but proportionate) concentrations of TCA compared to TCE likely relate to its greater degradability (Scheutz et al., 2011).

\section{a) July 2006}

River stage

b) January 2007
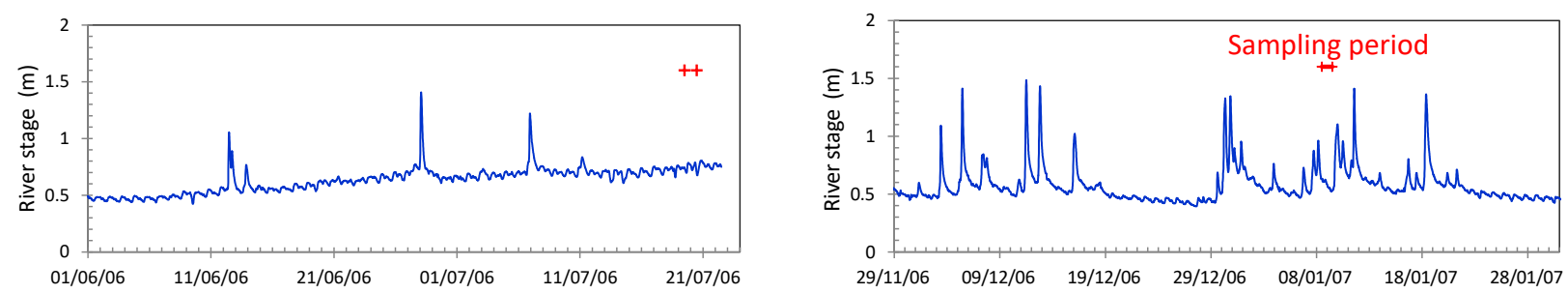

\section{Total Chloroethenes}
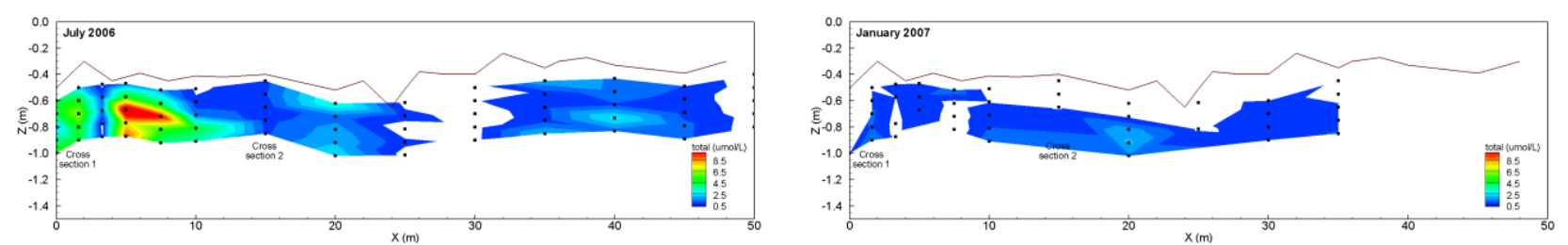

TCE
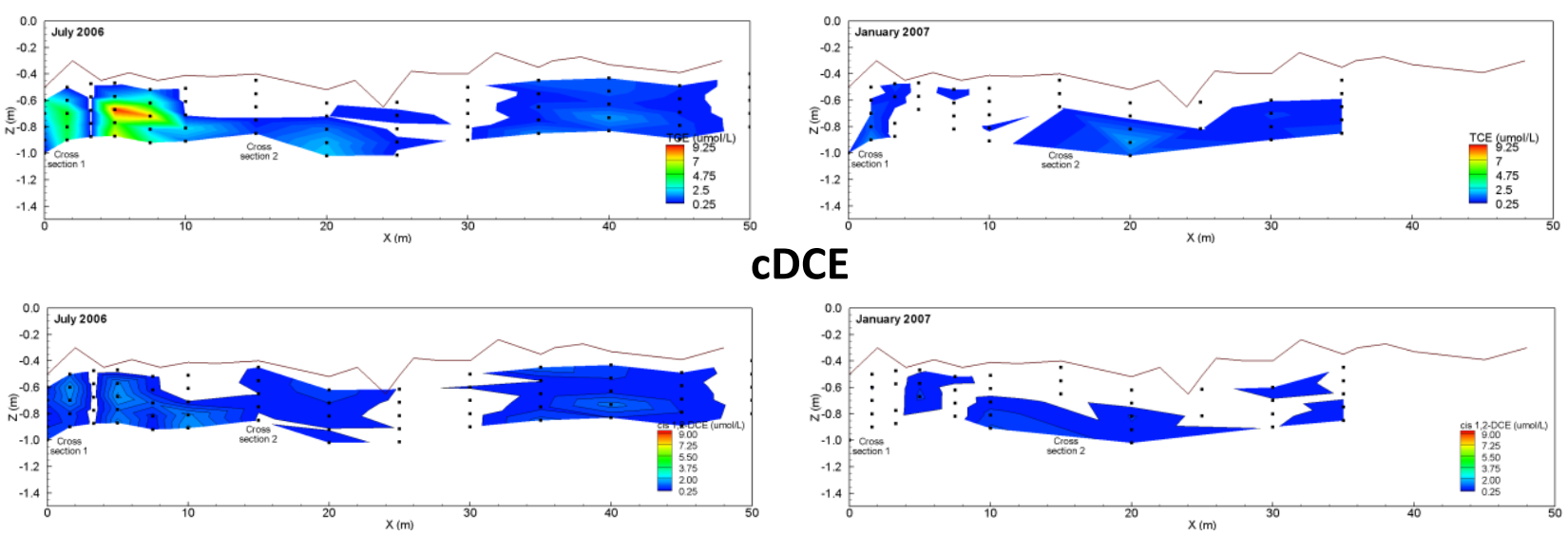

VC
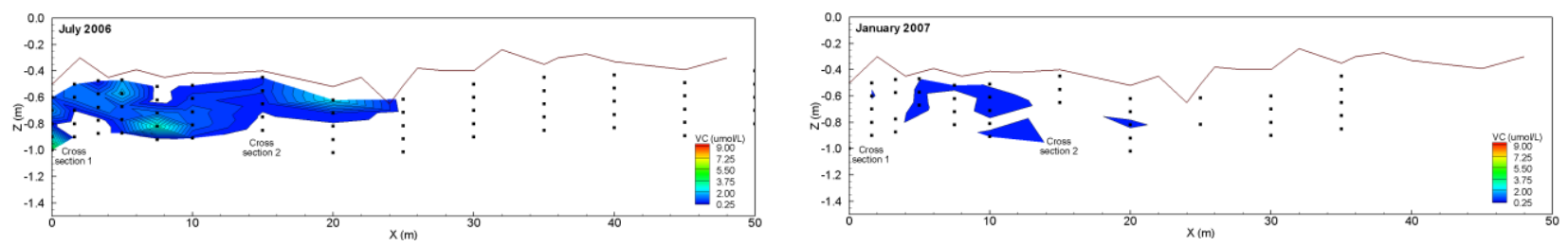

Fig. 7. North bank Longitudinal Transect concentrations ( $\mu \mathrm{mol} / \mathrm{L})$ for Total chloroethenes, TCE, cDCE and VC are shown for July 2006 and January 2007. Accompanying river stage data from the Environment Agency gauged site $500 \mathrm{~m}$ downstream are shown with the $\mathrm{CHC}$ plume water-quality sampling periods indicated. 
Fig. 7a shows data for July 2006, a period of elevated concentrations and low river stage when groundwater baseflow contributions were dominant. The river stage gradually increases during the summer due to macrophyte growth within the (gauged) river channel. Greatest concentrations of around $10 \mu \mathrm{mol}(>1000$ $\mu \mathrm{g} / \mathrm{L}$ ) for TCE and total chloroethenes occurred in the upstream reach over $x 0-15 \mathrm{~m}$ and locally at $x 20 \mathrm{~m}$. Concentrations of cDCE were similar in magnitude in both upstream and downstream parts of the Longitudinal Transect. However, further dechlorination to VC was only observed in the upstream section.

Minimum CHC plume concentrations were observed in January 2007 (Fig. 7b). The accompanying river stage data indicate sampling occurred during a wet (winter) period with the actual sample period largely falling between two immediately adjacent precipitation related peaks in river stage, but with some sampling undertaken on a rising hydrograph limb. The absence of CHC concentrations in shallow horizons over the $x$ $=10-25 \mathrm{~m}$ interval (compare Figs. $7 \mathrm{a}$ and $7 \mathrm{~b}$ ) is attributed to the invasion of surface water into the riverbed under these hydrological conditions. This invasion may cause discharging $\mathrm{CHC}$ concentration plume dilution and lateral plume displacement. The absence of total chloroethenes to depth in parts of the $x=0-10 \mathrm{~m}$ reach suggest that surface water may be locally invading to depth and corroborate the earlier chloride data that indicate this part of the riverbed may be subject to transient dynamic flow influences. The presence of VC is much decreased (compare Figs. 7a,b) with VC only seen in the vicinity of $x=10 \mathrm{~m}$ (ML6).

The Cross Sections 1 and 2 (Fig. 8) provide strong evidence that the source of the CHC plumes are to the north of the river. Whilst there is some spread of the parent solvent TCE towards the river midpoint, and to a lesser extent cDCE in Cross Section 2, the majority of plume detections and highest concentration occur within 3 to $4 \mathrm{~m}$ of the north bank. Dechlorination to $\mathrm{VC}$ is only evident in even closer proximity to the bank. Greater concentrations of dechlorination products cDCE and VC generally occur at shallower horizons, particularly in Cross Section 2. Cross Section 1 exhibits a more complex distribution. Higher TCE concentrations occur at both shallow and deep points. There is extension at depth of just the TCE plume to around mid river channel.

a) Cross Section 1

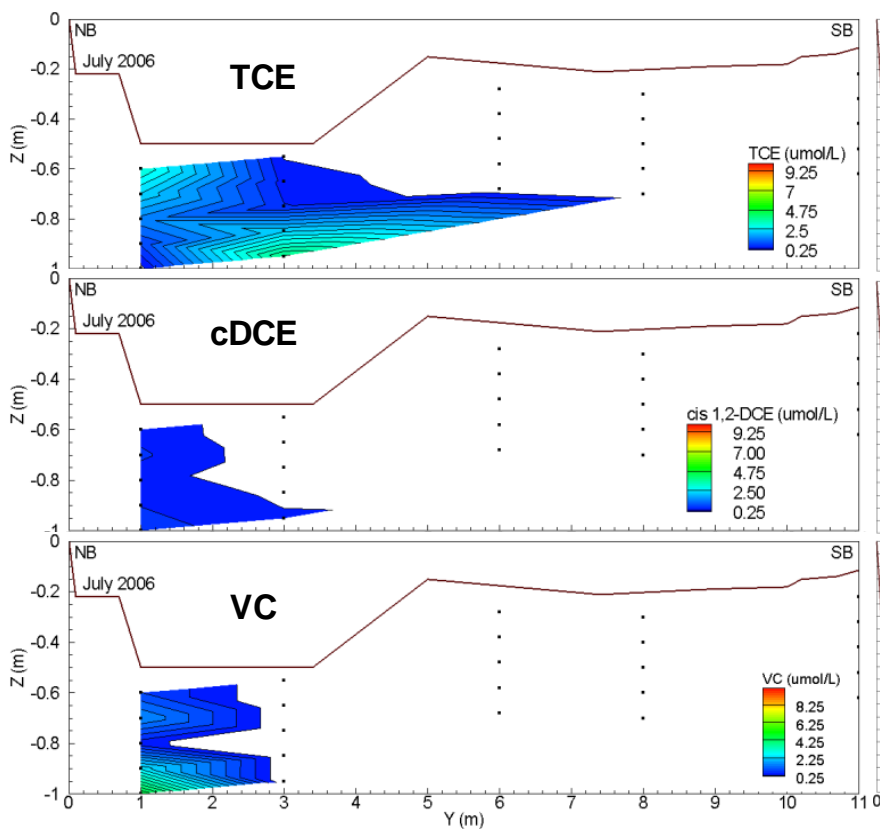

b) Cross Section 2

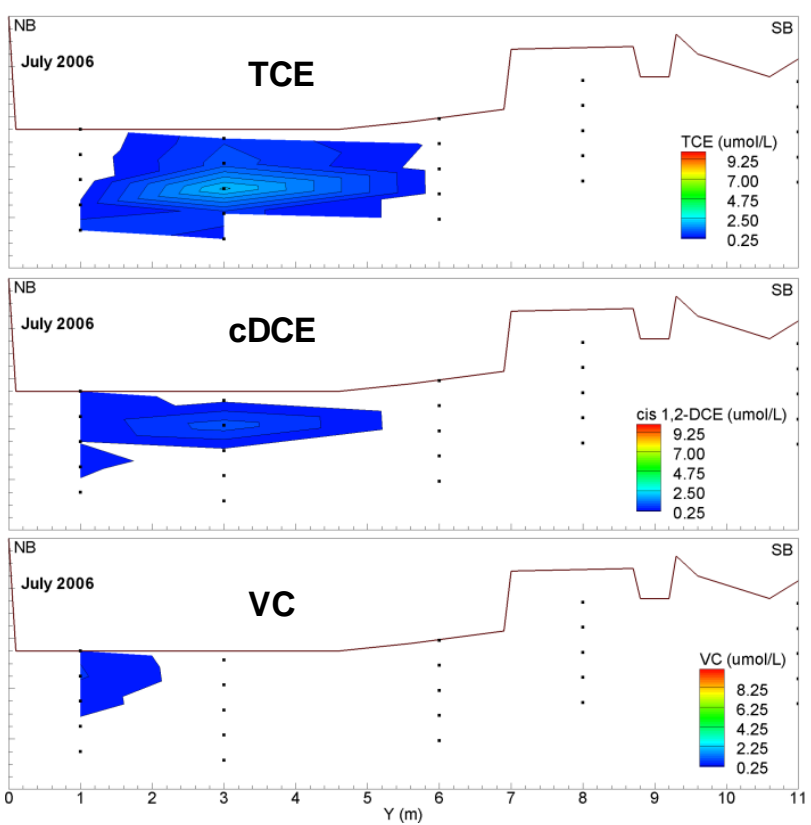


Fig. 8. Cross Sections 1 and 2 concentrations $(\mu \mathrm{mol} / \mathrm{L})$ for Total Chloroethenes, TCE, cDCE and VC. NB: North Bank; SB: South bank.

\subsubsection{Specific multilevel sampler (depth profile) assessment}

Selected multilevel depth profiles from the Longitudinal Transect in Fig. 9 illustrate the contrasting dechlorination activity observed along the reach. These were obtained at the sampling event that included ethane/ethane data. This hence allowed assessment of dechlorination reaction mass balance (assuming the approximation of simple vertical upward flow in the profiles).
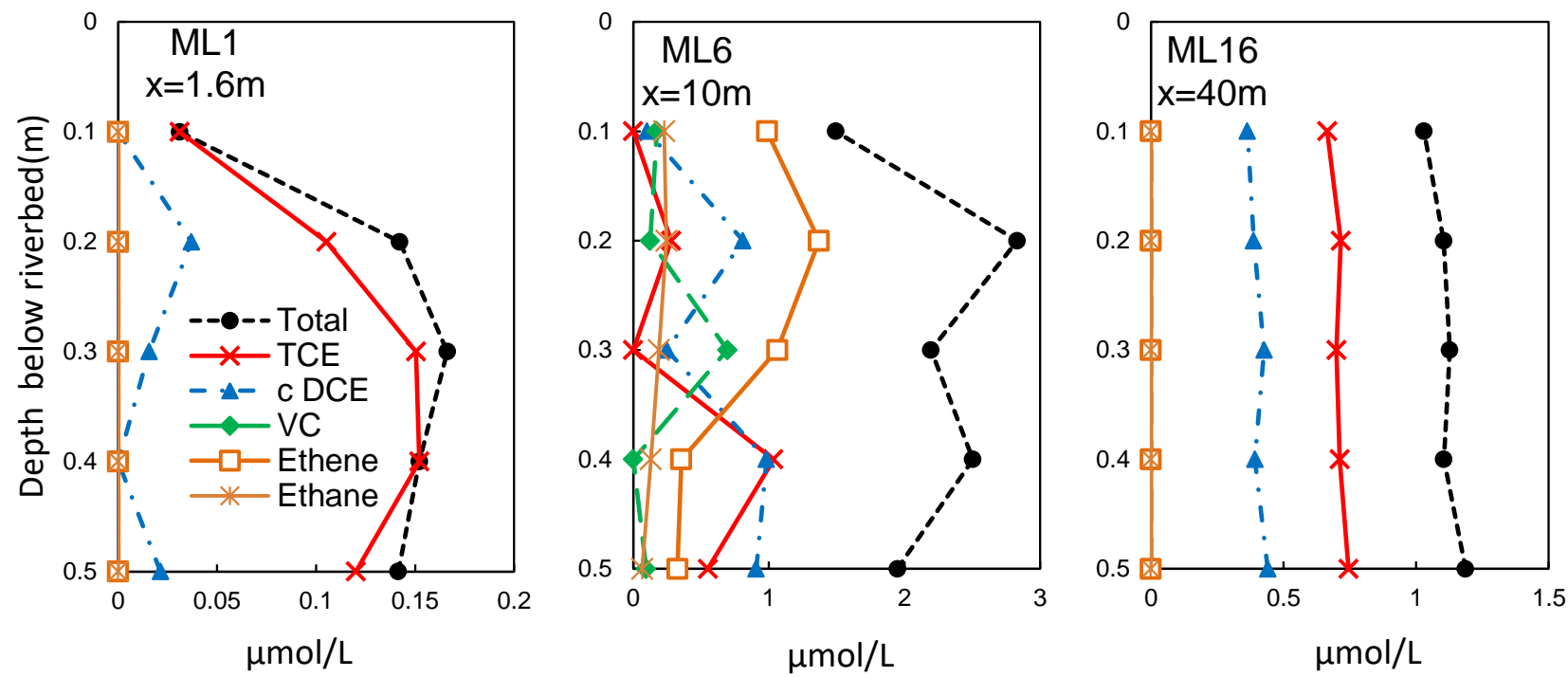

Fig. 9. Concentration depth profiles from the north bank Longitudinal Transect at $x=1.6 \mathrm{~m}, 10 \mathrm{~m}$ and $40 \mathrm{~m}$, in September 2007 ('Total' is the sum of CHCs, ethene and ethane).

ML1 is the least easily explained profile, displaying moderately constant Total concentrations between 0.5 and $0.2 \mathrm{~m}$ depth. There is some dechlorination evident, but a sharp decrease in concentration at $0.1 \mathrm{~m}$ is potentially related to flow controls associated with the shallow low permeability deposits present in this upstream part of the reach. Chloride profiles in ML1 are very variable with time and with depth and suggest that dilution of $\mathrm{CHC}$ plumes may occur both near surface, but also at depth in the profile under transient river stage conditions.

ML6, at $x=10 \mathrm{~m}$, exhibits a classic dechlorination profile of decreasing TCE and intermediate peaks representing transient production of $\mathrm{CDCE}$ and VC. It culminates with ethene dominating and some ethane in the shallowest samples. Mass balance was not maintained close to the riverbed in ML6 (i.e., decline in total) and is ascribed to some dilution by surface water mixing. This is supported by chloride data at this locality. Approximately $50 \%$ of the total $\mathrm{CHC}$ is converted to ethene in the $0.3 \mathrm{~m}$ pathway ( 0.5 to $0.2 \mathrm{~m}$ depth) through the riverbed. ML6 displays low concentration chloride at depth. However, the shallowest point at $0.1 \mathrm{~m}$ typically contains increased chloride signifying very shallow hyporheic zone surface-water invasion and mixing with the $\mathrm{CHC}$ discharge at the interface. Application of Eq. (1) and chloride data (not available at this date but July 2006 data used having similar hydrological conditions), indicates a $f_{s w}$ of 0.35 in the $0.1 \mathrm{~m}$ deep 
monitoring point. Using this figure, a dilution-corrected Total concentration of $1.9 \mu \mathrm{mol} / \mathrm{L}$ is obtained. This is very similar to the deeper groundwater concentration (Fig. 9). Assuming uniform upward flow, $82 \%$ of the discharging mass at ML6 is ethene/ethane; this represents the maximum CHC conversion observed in the reach.

ML16 at $x=40$ m exhibits remarkably constant CHC concentrations with depth indicating an absence of both dechlorination activity and surface-water mixing and dilution in the riverbed. This observation alongside uniform cDCE concentrations suggests that $\mathrm{CDCE}$ was formed in the upgradient aquifer. The CHC interpretation is supported by the estimated surface-water fractions shown in Fig. 5; the ML16 chloride profile is near constant with depth. The data suggest simple groundwater plume discharge with no attenuation due to dechlorination and an absence of hyporheic zone - surface water mixing.

\subsubsection{Temporal CHC concentration variability}

ML6 depth-profile data are shown in Fig. 10 illustrating the temporal variation of dechlorination activity. The accompanying river-stage hydrograph indicates the 12 sampling dates covered a wide range of hydrological and seasonal conditions as well as providing data close in time (Figs. 10d,e,f,g span a week period). Plots exhibit CHC decline towards the sediment surface. TCE and CDCE concentrations at depth $(0.4-0.5 \mathrm{~m})$ were generally around $1-2 \mu \mathrm{mol} / \mathrm{L}$ although higher concentrations up to $7 \mu \mathrm{mol} / \mathrm{L}$ were observed suggesting some variability in concentrations entering the riverbed. Ethene/ethane data were only available for Fig. 10k (the plot already discussed as Fig. 9b) and hence although Fig. 10 is generally confirmatory of the effective decline of CHCs as the riverbed is approached, the data are unfortunately not unequivocal in discerning the relative importance of dechlorination to ethane/ethane, dilution by surface water mixing and oxidative losses of CHCs. 

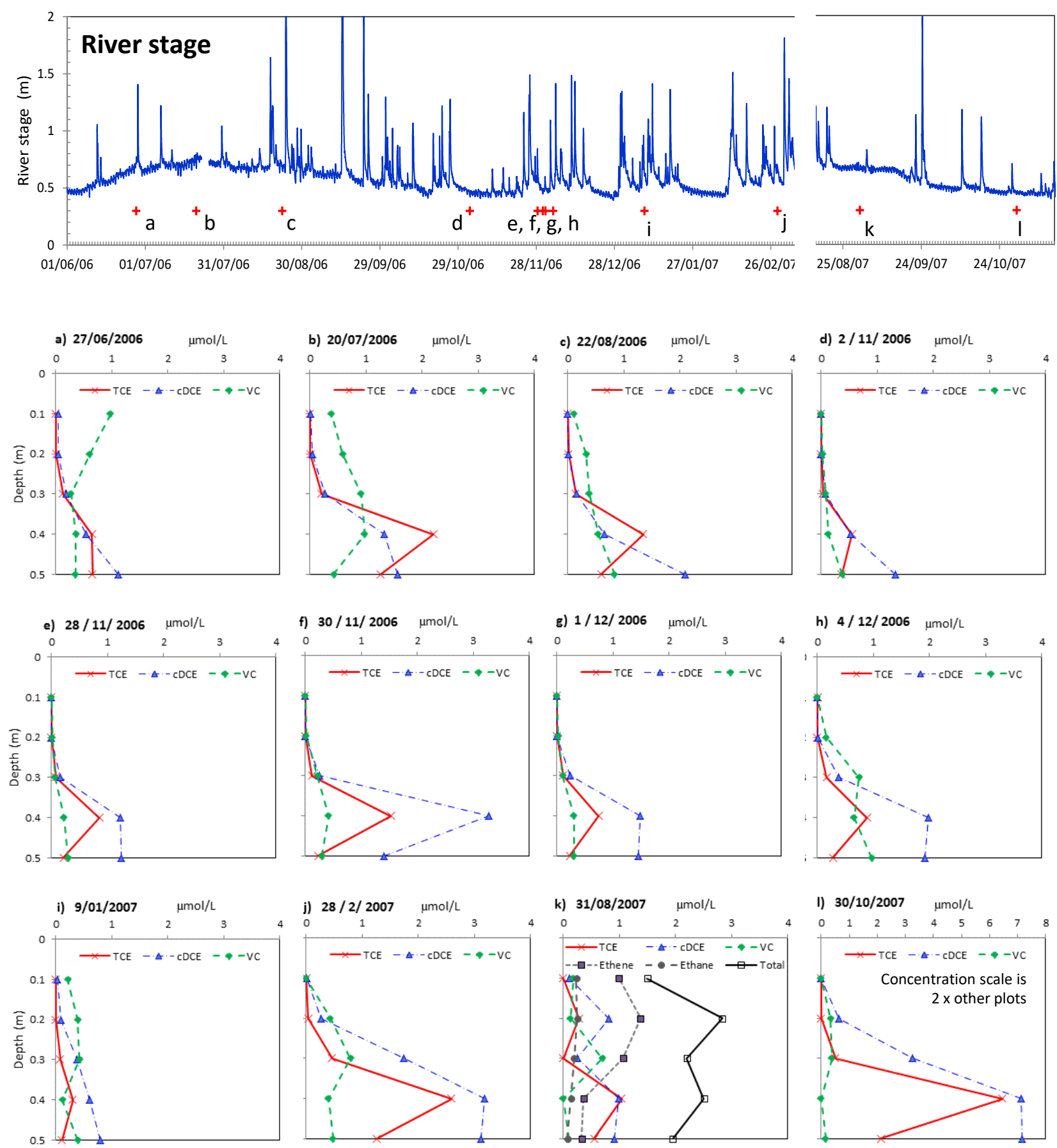

Fig. 10. CHC depth profiles shown at different dates for ML6 at $x 10 \mathrm{~m}$. Sample dates for each plot are marked on the river stage hydrograph.

Steepest declines in cDCE and TCE were at $0.3-0.4 \mathrm{~m}$ depth and were variously accompanied by increase and decrease of VC. The available ethane/ethane data for Fig. 10k suggest VC can be quite transient and ethene/ethane is probably readily produced in other profiles, particularly those exhibiting a VC peak (Figs. $10 \mathrm{~b}, \mathrm{f}, \mathrm{h}, \mathrm{i}, \mathrm{j}, \mathrm{k}, \mathrm{l})$. Where all CHCs have declined to detection limit (or low concentration) at both 0.1 and $0.2 \mathrm{~m}$ depth (Figs. 10d,e,f,g,h), examination of the Fig 10 hydrograph suggests that this is most likely due to surface-water mixing to these depths since times coincided with occurrences of recent river stage increases due to precipitation events. The CHC concentrations to $0.5 \mathrm{~m}$ depth in Fig. 10i are low compared with those present during very high winter stage conditions and have been presented in Fig. 7 and discussed above. The 
invading surface water may provide surface water organic matter electron donors for dechlorination at the time of invasion and later as invaded water persists or organic matter is retained.

\subsection{Observed dechlorination variability}

Log molar ratios of cDCE to TCE and of VC to TCE for the Longitudinal Transect are shown in Fig. 11a,b. As significant upward flow components are evident from the nearly horizontal potentiometric lines (Fig. 4) and plume discharge occurs close to the north bank (Fig. 8), we assume as a first approximation that flow is quasi-vertical in the Longitudinal Transect. The ratio data confirm dechlorination to cDCE (Fig. 11a) was generally limited at depth, but was locally significant and increased at shallow depths, particularly over the 0 - $32 \mathrm{~m}$ reach interval. Further dechlorination to $\mathrm{VC}$ was also restricted to the upgradient part of the reach (Fig. 11b) and more evident in shallower horizons as may be anticipated for this later stage dechlorination product. Low, more constant, ratios at $x>c .30 \mathrm{~m}$ confirmed insignificant dechlorination to cDCE and an absence of VC formation. Similar concentrations and ratios at all depths within the $x>30 \mathrm{~m}$ glide section (except at $x=50 \mathrm{~m}$ ) infer that dechlorination occurred in the aquifer prior and not riverbed sediments. 

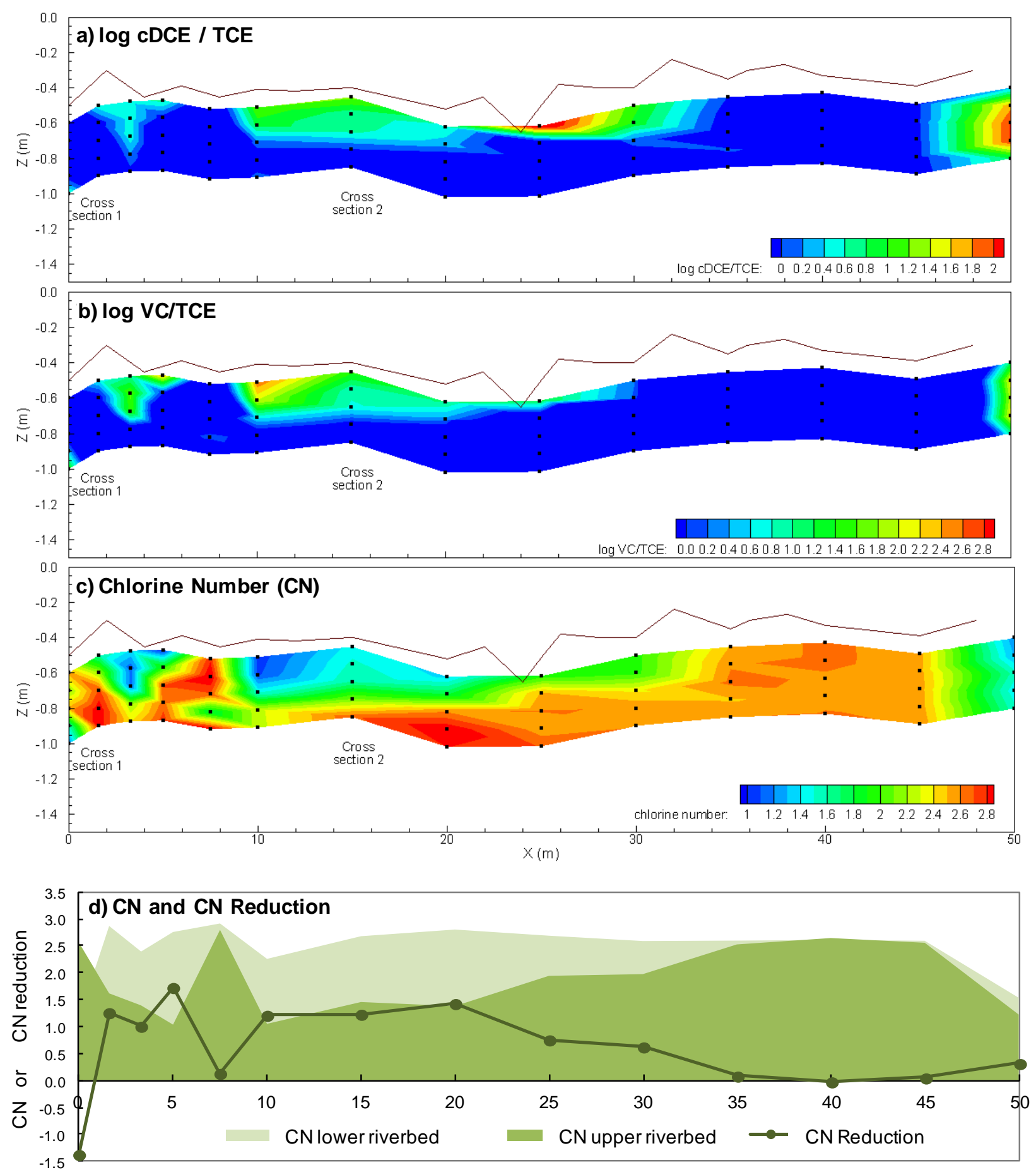

Fig. 11. North bank Longitudinal Transect showing: contoured molar concentration ratios for a) $\log (\mathrm{cDCE} / \mathrm{TCE})$ and b) $\log (\mathrm{VC} / \mathrm{TCE})$; c) contoured Chlorine Number (CN) (ethene not included in $\mathrm{CN}$ calculation as insufficient data are available); and, d) upper riverbed and lower riverbed $\mathrm{CN}$ values and CN Reduction values.

The 'Chlorine number' (CN) plot (Fig. 11c) provides an alternative, more direct, presentation of dechlorination variation. CNs approaching 3 (the value for TCE alone) indicating an absence or low occurrence of dechlorination occur over much of the $x=25-45 \mathrm{~m}$ reach. Decreased CNs providing evidence 
of significant dechlorination occurred at shallow depths over $x=10-32 \mathrm{~m}$. From $x=0-10 \mathrm{~m}, \mathrm{CN}$ distributions were complex showing areas of both dechlorination occurrence and absence.

Fig. 11d presents the $\mathrm{CN}$ reduction profile observed between the deepest and shallowest multilevel points with these lower and upper boundary $\mathrm{CN}$ values also shown as shaded block trends along the Longitudinal Transect. The plot does not include ethene data as these were not available for all points sampled. Fig. 11d provides a useful visual and quantitative indicator of the attenuation capacity due to dechlorination activity. The reach from $x 0-20$ m shows a relatively constant $\mathrm{CN}$ reduction of around $1-1.5$ units (atoms of chlorine dechlorinated). There is some variability probably due to the complex flow regime (see discussion of Fig. 5). Potentially non-vertical flow accounts for the wide variation in $\mathrm{CN}$ reduction around $x=5 \mathrm{~m}$ (and $x=0 \mathrm{~m}$ where negative values are calculated as $\mathrm{CN}$ values are higher at shallow depth). Where dechlorination to ethene does occur (for example at $x=10 \mathrm{~m}$, Fig. 9b), CN reduction would be somewhat greater than depicted in Fig. 11c,d. The $x=20-35 \mathrm{~m}$ reach exhibits an approximately linear decline in $\mathrm{CN}$ reduction from 1.5 to zero suggesting gently declining dechlorination activity. Near zero $\mathrm{CN}$ reduction (inactive dechlorination) largely occurs over $x 35-50 \mathrm{~m}$.

\subsection{CHC impact on surface water}

Surface-water samples (2006) from immediately above the riverbed sampling points indicate TCE concentrations close to the detection limit of $0.5 \mu \mathrm{g} / \mathrm{L}(0.004 \mu \mathrm{mol} / \mathrm{L})$, with an observed maximum of 0.83 $\mu \mathrm{g} / \mathrm{L}(0.0063 \mu \mathrm{mol} / \mathrm{L})$. $\mathrm{cDCE}$ showed sporadic detections just above a similar detection limit. VC was not detected. A very small rise in TCE concentrations along the river reach is suggested by the October 2006 data with surface water concentrations over the 0 - $15 \mathrm{~m}$ reach averaging $0.57 \pm 0.10 \mu \mathrm{g} / \mathrm{L}(\mathrm{n}=7)$ compared to $0.63 \pm 0.09 \mu \mathrm{g} / \mathrm{L}(\mathrm{n}=7)$ for the $15-50 \mathrm{~m}$ reach. The increase of $0.06 \mu \mathrm{g} / \mathrm{L}$, although very small, is consistent with scoping calculations of the impact of groundwater plume discharge concentrations from our observed riverbed data. Using averaged maximum $\mathrm{CHC}$ concentrations from the upper $0.3 \mathrm{~m}$ of riverbed and assuming a discharging CHC plume footprint of $50 \mathrm{~m}$ by $5 \mathrm{~m}, K$ of $1.5 \mathrm{~m} / \mathrm{d}$ and $i$ of 0.15 , gives a plume discharge of $56 \mathrm{~m}^{3} / \mathrm{d}$ that will be diluted 2700 fold by the receiving river (assuming Environment Agency low flow discharge data of $150,000 \mathrm{~m}^{3} / \mathrm{d}$ ), we obtain comparable surface-water concentration increases in TCE of $0.08 \mu \mathrm{g} / \mathrm{L}$ (cDCE $0.02 \mu \mathrm{g} / \mathrm{L}, \mathrm{VC} 0.01 \mu \mathrm{g} / \mathrm{L})$.

The gradient of TCE river concentration increase at our site is 4.5 times the mean $0.28 \mu \mathrm{g} / \mathrm{L}$ TCE increase per $\mathrm{km}$ of river reach observed in 2001 by Ellis and Rivett (2007) over the $7 \mathrm{~km}$ reach of the Tame passing through Birmingham. This higher value is not unreasonable and reflects the specific plume input to the river at our site. It should also be recognized that $\mathrm{CHCs}$, as volatile, will be lost from the river during transport downstream. The half-life for TCE loss through surface-water - atmosphere partitioning calculated for the 7 $\mathrm{km}$ reach using the method of Rathbun (2000) is $0.1 \mathrm{~d}$ and is comparable to the $0.15 \mathrm{~d}$ residence time of that reach length. The above surface water concentrations for TCE are low compared to the inland surface waters annual average Environmental Quality Standard (EQS) set for TCE of $10 \mu \mathrm{g} / \mathrm{L}$ (Substance 29b in European Directive 2008/105/EC). There are no EQS values set for cDCE or VC.

\section{Discussion of dechlorination variation}

\subsection{Variation and controls at the sub-reach scale}

The $50 \mathrm{~m}$ long reach exhibited contrasting CHC dechlorination, both in space and time. Due to the pronounced spatial and temporal heterogeneity observed in site properties and dechlorination activity, we accept that broad classifications of sub-reach behavior can only be made at present without yet further 
intensification of data collection from what is already a detailed study. We propose that the reach may be classified into three sub-reaches of contrasting dechlorination behavior and controlling processes as discussed below.

\subsubsection{Sub-reach from $x=10$ to approximately $30 \mathrm{~m}$ : Riffle section}

The sub-reach $x=10-30 \mathrm{~m}$, primarily a riffle section, exhibits significant dechlorination within the riverbed, particularly over $10-20 \mathrm{~m}$. ML6 at $x=10 \mathrm{~m}$ exhibited the most complete dechlorination (Fig. 9b). The sub-reach was characterized by hyporheic zone flows, moderate sulphate concentrations and $\mathrm{pH}$, low dissolved oxygen and $\mathrm{E}_{\mathrm{H}}$ and hence anaerobic conditions and the presence of low iron, but elevated manganese concentrations. Sulphate reduction was inferred from trace sulphide occurrence, olfactory detection of hydrogen sulphide gas, and depressed sulphate concentrations relative to the downstream reach. ML6, although displaying maximum dechlorination activity, exhibited a low $f_{o c}$ throughout its core (c. $0.5-$ $1 \%$ ) suggesting the relatively low sediment $f_{o c}$ did not impede reductive dechlorination.

The occurrence of temporally variable surface-water invasion into the riverbed forming a transient hyporheic mixing zone appears of key importance in this sub-reach. Combined with the observed low sedimentary $f_{o c}$, it is inferred that the transient invasion of Tame river water typically containing DOC at $4-10 \mathrm{mg} / \mathrm{L}$ to varying riverbed depths may be a significant source of dissolved or particulate organic matter that may rejuvenate the hyporheic zone and drive dechlorination occurrence. Surface-water invasion may be facilitated by the high energy - riffle nature of this sub-reach and variable riverbed topography. Rapid rises in stage of this somewhat flashy urban river may potentially induce deep transient penetration of the river bed and extension of the hyporheic zone to depth. The freeze core from very close to ML6 (Fig. 2, Core 2) shows very poorly sorted deposits over the $0.2-0.4 \mathrm{~m}$ depth interval where dechlorination is most evident (Fig. $8 b$ ). Some dark staining potentially indicating reducing conditions beneath some large cobbles / boulders may arise from impeded tortuous flow and increased residence times.

For dechlorination to occur in the mixed discharging groundwater plume and invading surface water, any DO present will need to be consumed first. Whilst DO concentrations remain, however, aerobic oxidation of the LCHC's particularly VC is expected (Gossett, 2010). Examining our VC occurrence and surface water invasion data (compare Figs. 5 and 7), we predict that, if occurring, VC aerobic oxidation (that remains difficult to prove at the field scale) would be most probable over the $x=10$ to $25 \mathrm{~m}$ interval of the reach close to the north bank. Oxidation of LCHCs to $\mathrm{CO}_{2}$ is also possible under anaerobic conditions using alternative electron acceptors to oxygen. The oxidation of cDCE by manganese (IV) oxides observed in lab studies on streambed sediments (Bradley et al., 1998) may perhaps contribute to the elevated manganese observed. Whilst our analysis of ML6 dechlorination shows reasonable mass balance, uncertainties in that balance do not preclude some conversion of LCHCs to $\mathrm{CO}_{2}$ being mediated by reductive dissolution of sediment manganese oxides. However, the occurrence of anaerobic oxidation by manganese and other electron acceptors is questioned by Gossett (2010) who indicate that low, difficult-to-measure, concentrations of oxygen may have still been present in previous studies that were sufficient to cause aerobic oxidation and, also, that anaerobic oxidizers of VC and DCEs have eluded isolation.

\subsubsection{Sub-reach $x=$ approximately $30-50 \mathrm{~m}$ : Glide section}

There was an absence of riverbed dechlorination observed over much of the $x=30-50 \mathrm{~m}$ sub-reach, a glide section, despite some of the sediments having a reduced, grey-coloured, appearance (Fig. 2). Contrasting features compared to the reach upstream (Section 4.1.1) include more elevated sulphate concentrations in the upstream part of this sub-reach, increased $\mathrm{DO}$ and $\mathrm{E}_{\mathrm{H}}$ that give rise to mildly oxic conditions, decreased but still significant manganese in the upstream part of the sub-reach, and little hyporheic zone flow. The absence of dechlorination is consistent with the process-based interpretation given earlier in that surface-water invasion appears absent and hence river-based provision of organic matter to the riverbed and enhancement 
of dechlorination fails to occur. Simple groundwater discharge occurs with little evidence of a (permanent or transient) hyporheic zone establishing in this glide part of the reach. The lack of dechlorination is consistent with transition in this sub-reach to oxic conditions towards the more downstream parts of this sub-reach that would prevent dechlorination activity.

Further, the sulphate high-concentration plume core generally coincided with the zone of insignificant or absent dechlorination at around $x=30-45 \mathrm{~m}$ where sulphate frequently exceeded $300 \mathrm{mg} / \mathrm{L}$. The lack of dechlorination is consistent with the field and laboratory observations of Pantazidou et al. (2012), who indicate sulphate concentrations above $250-300 \mathrm{mg} / \mathrm{L}$ inhibit dechlorination, particularly of cDCE and VC. It is reasonable to infer from these observations that the TCE plume partially degraded to CDCE local to its source, but subsequently comingled with a high-concentration sulphate plume generated from a downgradient source that subsequently inhibited dechlorination. The $\mathrm{pH}$ over this sub-reach (and wider site) was not likely to be inhibitory as it is within the optimal range of 6 to 8 for dechlorination (Brovelli et al., 2012; Robinson et al., 2009).

In summary, a combination of factors may contribute to the lack of dechlorination observed in this sub-reach - inhibition by elevated sulphate concentrations, a predominant baseflow condition and absence of a hyporheic zone, oxic conditions and the lack of rejuvenation (fresh organic matter supply) of the riverbed. The present dataset does not allow discrimination of their relative importance.

\subsubsection{Sub-reach $x=0-10 \mathrm{~m}$ : End-of-pool-riffle section}

The $x=0-10 \mathrm{~m}$ sub-reach appears more complex with both significant and negligible dechlorination occurring in close proximity within this pool tail-end - riffle section of the reach (Fig. 11). The complexity may arise from several factors, including variable topography where the pool gives way to a riffle section; the anthropogenic influence of the bankside pipe discharge; contrasting sediment permeabilities that notably include low permeability high $f_{o c}$ silty material; stage-influenced dynamic riverbed flow regimes; and, potential flow bypass of the high attenuation capacity silty fine-grained layers where contaminant transport may be more diffusion based (White et al., 2008). The high $f_{o c}$ shallow sediments appear readily renewed through deposition in the slower flowing pool - willow tree - pipe discharge area. They are likely to provide a ready source of labile carbon as evidenced by the maximum methane concentrations encountered. Methanogenesis may, however, competitively suppress dechlorination (Yang and McCarty, 2000). Such suppression alongside bypassing of high attenuation silty zones via more permeable horizons may potentially account for the patchy nature of dechlorination.

\subsection{Conceptual model}

A conceptual model illustrating controls on the reach-scale variability of $\mathrm{CHC}$ dechlorination is shown in Fig. 12. The figure is based on the findings associated with the Longitudinal Transect using the riverbed topographic profile from that transect. It presents example path (flow) lines that illustrate possible routes of $\mathrm{CHC}$ solute migration with a brief narrative on controlling processes that may influence plume fate. Greatest dechlorination is illustrated in the mid-section, riffle part, of the reach, where surface water mixing is most significant; minimal dechlorination and high groundwater baseflow discharge is shown in the downstream glide section; and variable attenuation is shown the upstream pool - riffle section with the influence of the low permeability silt deposit indicated. Each narrative is intended to be of generic value, but also pertinent to the study site. 


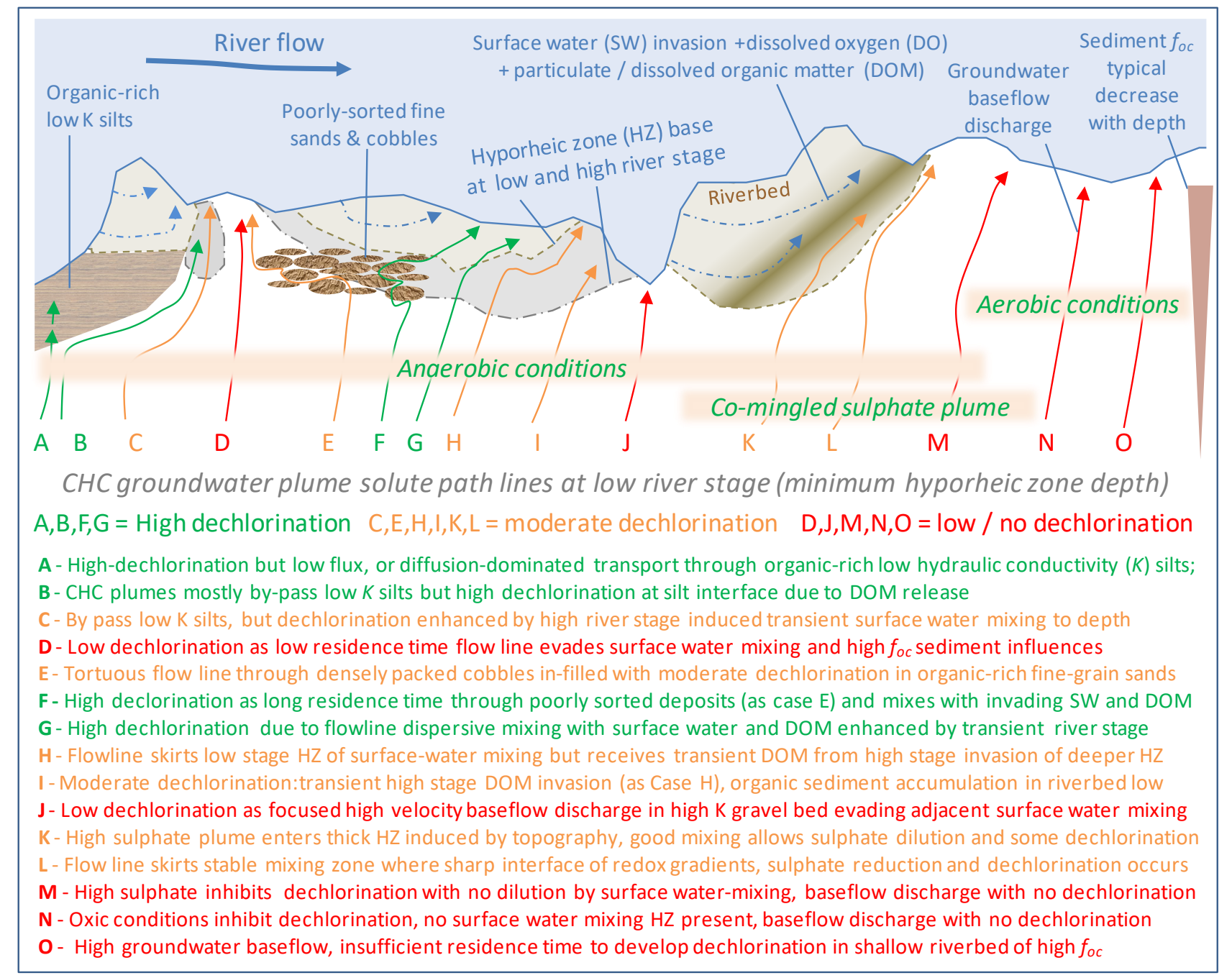

Fig. 12. Conceptual model illustrating controls on the reach-scale variability of CHC dechlorination based on the study findings. Example path (flow) lines with brief accompanying narrative are shown for possible migrations of dissolved-phase CHC solute in a discharging plume under conditions of low river stage and shallow hyporheic zone flow. Some solute path lines (H,L) are depicted circumventing the hyporheic zone of invading surface-water flow at low river stage. Others $(\mathrm{F}, \mathrm{G}, \mathrm{K})$ are shown entering the shallow hyporheic zone due to dispersive mixing. Although circumventing the base of the hyporheic zone at low river stage, some path lines (B,C,H,I) still pass through sediment volumes that have been previously invaded by hyporheic zone flows under high river-stage conditions.

We highlight the importance of mixing within the hyporheic zone of the discharging CHC plume with invading surface water containing organic matter. Dechlorination will be most significant where there is effective mixing of groundwater and surface water, particularly if the invading organic matter is the key source of electron donor, rather than the resident sedimentary organic matter. It is probable that the latter is generally less bioavailable, especially where sedimentary organic matter has become more recalcitrant with age. The presence of a hyporheic zone does not necessarily guarantee a significant amount of mixing of organic matter-rich surface water with $\mathrm{CHC}$-rich groundwater discharge. In the inner parts of a large 'streamtube' of surface-water flow though the hyporheic zone, there may be very limited, if any, mixing with groundwater. Most effective mixing of the surface water and groundwater flow lines is likely to be on the 
peripheries of the hyporheic zone where transverse mechanical dispersion and solute diffusion may enhance organic matter - CHC contact and induction of suitable biogeochemical conditions for dechlorination. The degree of transients and variation in depth of active hyporheic zone flow is potentially more important than the absolute size of the zone. This is due to the potential of transients to increase dispersive mixing processes, replenishment and possible retention of organic matter (for example organic matter particle straining) and the dynamic cycling of sediment-related redox systems, for example, manganese and iron.

\section{Conclusions}

The urban reach-scale study of a discharging TCE groundwater plume has allowed detailed observation of dechlorination variability within the riverbed - hyporheic zone and has provided field-scale insight into controlling processes. It is distinguished from previous detailed CHC study sites elsewhere by its predominant riffle - glide high energy urban river reach setting and heterogeneous riverbed nature. Riverbed characterisation and monitoring methods implemented secured a high spatial resolution CHC dataset using manual cost-effective approaches. The riverbed was shown, primarily through freeze coring, to be geologically heterogeneous and poorly sorted. CHC plume distributions and dechlorination occurrence within the riverbed were shown to be transient and sensitive to river stage and antecedent conditions. The extent of hyporheic zone flow was river stage dependent with a deeper hyporheic zone generally present after precipitation-related river-stage increases, especially if surrounding groundwater levels were low. A $\mathrm{CHC}$ chlorine number reduction approach was useful as a convenient metric of dechlorination as it provides advantages of simplicity, circumvents dilution issues and is a whole dechlorination sequence measure. It appears to have received limited use for dechlorination assessment at CHC-contaminated sites.

Three sub-reaches of contrasting dechlorination behaviour were identified. Greatest dechlorination occurred in the $x=10-30 \mathrm{~m}$ predominantly riffle sub-reach and was attributed to stage-related transient surfacewater mixing into the riverbed yielding a variation in depth of active hyporheic zone flow. Continuous input to variable depth of river-based organic matter is anticipated to be the key control on driving dechlorination reactions and maintenance of low redox conditions in this sub reach. Up to around $80 \%$ conversion to ethene / ethane was observed locally. In contrast the downstream glide sub-reach at $x=30-50 \mathrm{~m}$ displayed a near absence of dechlorination. This was attributed to the predominant groundwater baseflow discharge condition, hyporheic zone absence (no surface water invasion and rejuvenation of the riverbed), transition to more oxic riverbed conditions along the sub-reach and local presence in part of the reach of very elevated sulphate concentrations observed in the literature to inhibit dechlorination. It has not been possible to discriminate on the relative importance of these factors. The $x=0-10 \mathrm{~m}$ sub-reach exhibited a contrasting patchy occurrence of dechlorination that can be attributed to sub-reach local complexity. It is probable that there was significant flow bypass of the low permeability high $f_{o c}$ silty material of high dechlorination potential. Also, methanogenesis arising from the very high $f_{o c}$ shallow sediments may potentially have competitively suppressed dechlorination.

From a wider management perspective, the study site, infers that riverbed - hyporheic zone $\mathrm{CHC}$ dechlorination may perhaps provide only a patchy barrier to $\mathrm{CHC}$ groundwater plume discharges to a surface-water receptor. Despite it being possible to broadly assign sub-reaches of differing dechlorination activity, this required a fairly large dataset and some findings still remain speculative pointing to the need for yet more targeted investigation and application of other techniques (e.g., isotope or molecular biological tools). The study illustrates that obtaining even moderate understanding of heterogeneity of CHC attenuation in space and time at the reach scale, represents a very significant investigation effort that will depend upon the (unknown) level of heterogeneity present. Deciding on what degree of monitoring is practical, is 
sufficient to resolve the heterogeneity present and is appropriate to decisions being made by practitioners will be challenging. Although dechlorination was not sufficient in the study case to prevent CHCs migration through the riverbed, dilution in the receiving surface water meant the river concentration increases were at trace levels. This may of course not be the case in lower flow receiving surface waters elsewhere, or where contributing contaminated site $\mathrm{CHC}$ sources are more significant.

On field-scale research needs at CHC-impacted reaches, quantitatively establishing the importance of dechlorination within dynamic hyporheic (surface water - groundwater mixing) zones due to the transient input of river-based organic matter electron donor under varying river stage - hydrological conditions is seen to be a priority. Its contribution should be established relative to dechlorination arising from in-situ riverbed sedimentary organic matter and the possible aerobic oxidation of LCHCs via mixing with invading oxic surface water (for which suitable techniques require development). The influence of transient hydrological conditions on other electron acceptor / donor systems (e.g., manganese and iron) that may influence abiotic/biotic dechlorination and other attenuation reactions at sites also needs to be better established.

\section{Acknowledgments}

The Environment Agency is acknowledged for research funding under their Hyporheic Zone research programme. John Davis and Jonathan Smith, formerly of the Agency, are thanked for their technical discussions and facilitation of the research. Birmingham City Council is acknowledged for their facilitation of the study. The University of Birmingham is acknowledged for their funding of Prof. Freitas' work under the Brazil Visiting Fellows Scheme.

\section{References}

Abe, Y., Aravena, R., Zopfi, J., Parker, B., Hunkeler, D., 2009. Evaluating the fate of chlorinated ethenes in streambed sediments by combining stable isotope, geochemical and microbial methods. J. Contam. Hydrol., 107, 10-21. http://dx.doi.org/10.1016/j.jconhyd.2009.03.002

Bencala, K.E., 2000. Hyporheic zone hydrological processes. Hydrol. Process. 14, 2797-2798. http://dx.doi.org/10.1002/1099-1085(20001030)

Bradley, P.M., 2000. Microbial degradation of chloroethenes in groundwater systems. Hydrogeol. J., 8, 104111. http://dx.doi.org/10.1007/s100400050011

Bradley, P.M., Landmeyer, J.E., Dincola, R.S., 1998. Anaerobic oxidation of [1,2-14C]Dichloroethene under Mn(IV)-reducing conditions. Appl. Environ. Microbiol., 64(4), 1560-1562.

Brovelli, A., Barry, D.A., Robinson, C., Gerhard, J.I., 2012. Analysis of acidity production during enhanced reductive dechlorination using a simplified reactive transport model. Adv. Water Resour., 43, 14 - 27. http://dx.doi.org/10.1016/j.advwatres.2012.04.001.

Cardenas, M.B., Wilson, J.L., 2007. Exchange across a sediment-water interface with ambient groundwater discharge. J. Hydrology, 346, 69- 80. http://dx.doi.org/10.1016/j.jhydrol.2007.08.019

Cardenas, M. B., Wilson, J. L., Haggerty, R., 2008. Residence time of bedform driven hyporheic exchange, Advances in Water Resources, 31, 1382-1386 http://dx.doi.org/10.1016/j.advwatres.2008.07.006 
CEC (Council of the European Community), 2000. Directive 2000/60/EC of the European Parliament and of the Council of 23 October 2000 Establishing a Framework for Community Action in the Field of Water Policy. Official Journal of the European Communities, L327/1, 23.10.2000.

Chapman, S.W., Parker, B.L., Cherry, J.A., Aravena, R., Hunkeler, D., 2007. Groundwater-surface water interaction and its role on TCE groundwater plume attenuation. J. Contam. Hydrol., 91, 203-232. http://dx.doi.org/10.1016/j.jconhyd.2006.10.006

Conant, B., Cherry, J. a., Gillham, R.W., 2004. A PCE groundwater plume discharging to a river: influence of the streambed and near-river zone on contaminant distributions. J. Contam. Hydrol., 73, 249-279. http://dx.doi.org/10.1016/j.jconhyd.2004.04.001

Cox, E., Austrins, C., Spain, J., Shin, K., Nishino, S., Gossett, J., Giddings, C., Jennings, L., Edwards, E., Johnson, T., Duhamel, M., Sherwood Lollar, B., 2010. The truth is out there: unraveling the mystery of the missing cis-DCE, vinyl chloride and ethene. Battelle 7th international conference on remediation of chlorinated and recalcitrant compounds, Monterey, California, May 24-27, 2010, Abstract 629.

Cunningham III, J.J., Kinner, N.E., Lewis, M., 2009. Protistan predation affects trichloroethene biodegradation in a bedrock aquifer. Appl. Environ. Microbiol., 75 (24), 7588-7593. http://dx.doi.org/10.1128/AEM.01820-09

Cuthbert, M.O., Mackay, R., Durand, V., Aller, M.-F., Greswell, R.B., Rivett, M.O., 2010. Impacts of river bed gas on the hydraulic and thermal dynamics of the hyporheic zone. Adv. Water Resour., 33, 1347-1358. http://dx.doi.org/10.1016/j.advwatres.2010.09.014

Daily, S., Buss, S.B., 2014. Conceptual model report: Birmingham Sherwood Sandstone Aquifer investigation. Environment Agency Report 60101N R1.

Einarson, M.D., 2001. New low-cost, multi-level groundwater monitoring system. MSc dissertation, Department of Earth Sciences, University of Waterloo, Waterloo, Canada.

Ellis, P.A., Mackay, R., Rivett, M.O., 2007. Quantifying urban river-aquifer fluid exchange processes: A multi-scale problem. J. Contam. Hydrol., 91, 51-80. http://dx.doi.org/10.1016/j.jconhyd.2006.08.014

Ellis, P.A, Rivett, M.O., 2007. Assessing the impact of VOC-contaminated groundwater on surface water at the city scale. J. Contam. Hydrol., 91, 107-127. http://dx.doi.org/10.1016/j.jconhyd.2006.08.015

Environment Agency, , 2009. The Hyporheic Handbook - A handbook on the groundwater-surface water interface and hyporheic zone for environment managers. Environment Agency Integrated catchment science programme Science report: SC050070. Publ. Environment Agency, Bristol, UK. www.hyporheic.net/SCHO1009BRDX-e-e.pdf

Ford, M., Tellam, J. H., 1994. Source, type and extent of inorganic contamination within the Birmingham urban aquifer system, UK. J. Hydrol. 156, 101-135. http://dx.doi.org/10.1016/0022-1694(94)90074-4

Ford, M., Tellam, J.H., Hughes, M., 1992. Pollution-related acidification in the urban aquifer, Birmingham,

UK. J. Hydrol. 140, 297-312. http://dx.doi.org/10.1016/0022-1694(92)90245-Q

Freedman, D.L., Gossett, J.M., 1989. Biological reductive dechlorination of tetrachloroethylene and trichloroethylene to ethylene under methanogenic conditions. Appl. Environ. Microb., 55, 2144-2151.

Gossett, J.M., 2010. Sustained aerobic oxidation of vinyl chloride at low oxygen concentrations. Environ. Sci. Technol. 44, 1405-1411. http://dx.doi.org/10.1021/es9033974

Hamonts, K., Kuhn, T., Maesen, M., Bronders, J., Lookman, R., Kalka, H., Diels, L., Meckenstock, R.U., Springael, D., Dejonghe, W., 2009. Factors Determining the Attenuation of Chlorinated Aliphatic Hydrocarbons in eutrophic river sediment impacted by discharging polluted groundwater. Environ. Sci. Technol., 43, 5270-5275. http://dx.doi.org/10.1021/es8035994 
Hamonts, K., Kuhn, T., Vos, J., Maesen, M., Kalka, H., Smidt, H., Springael, D., Meckenstock, R.U., Dejonghe, W., 2012. Temporal variations in natural attenuation of chlorinated aliphatic hydrocarbons in eutrophic river sediments impacted by a contaminated groundwater plume. Water Res. 46, 1873 - 1888. http://dx.doi.org/10.1016/j.watres.2012.01.001

Kotik, M., Davidová, A., Voříšková, J., PBaldrian, P., 2013. Bacterial communities in tetrachloroethenepolluted groundwaters: A case study. Science of the Total Environment, 454-455, 517-527. http://dx.doi.org/10.1016/j.scitotenv.2013.02.082

Krause, S., K., Boano, F., Cuthbert, M.O., Fleckenstein, J.H., Lewandowski, J., 2014. Understanding process dynamics at aquifer-surface water interfaces: An introduction to the special section on new modelling approaches and novel experimental technologies. Wat. Resour. Res., 50(2) 1847-1855. http://dx.doi.org/10.1002/2013WR014755

Kuhn, T.K., Hamonts, K., Dijk, J. a, Kalka, H., Stichler, W., Springael, D., Dejonghe, W., Meckenstock, R.U., 2009. Assessment of the intrinsic bioremediation capacity of an eutrophic river sediment polluted by discharging chlorinated aliphatic hydrocarbons: a compound-specific isotope approach. Environ. Sci. Technol., 43, 5263-5269. http://dx.doi.org/10.1021/es803600s

Lorah, M.M., Burris, D.R., and Dyer, L.J., 2005. Natural Attenuation of chlorinated solvent ground-water plumes discharging into wetlands: U.S. Geological Survey Scientific Investigations Report 2004-5220. http://md.water.usgs.gov/publications/sir-2004-5220/

Maymo-Gatell, X.T., Anguish, T., 1999. Reductive dechlorination of chlorinated ethenes and 1,2dichloroethane by Dehalococcoides ethenogenes. Appl. Environ. Microbiol. 65(7), 3108-3113.

Maymo-Gatell, X., Tandoi, V., Gossett, J.M., Zinder, S.H., 1995. Characterization of an H2-utilizing enrichment culture that reductively dechlorinates tetrachloroethene to vinyl chloride and ethene in the absence of methanogenesis and acetogenesis. Appl. Environ. Microbiol. 61(11), 3928-3933.

McGuire T. M., Newell T. J., Looney B. B., Vangelas K. M., Sink S. H., 2004. Historical analysis of monitored natural attenuation: A survey of 191 chlorinated solvent sites and 45 solvent plumes. Remediation, 15(1), 99-112. http://dx.doi.org/10.1002/rem.20036

McKnight, U.S., Funder, S.G., Rasmussen, J.J., Finkel, M., Binning, P.J., Bjerg, P.L., 2010. An integrated model for assessing the risk of TCE groundwater contamination to human receptors and surface water ecosystems. Ecological Engineering, 36, 1126-1137. http://dx.doi.org/10.1016/j.ecoleng.2010.01.004

Moran, M.J., Zogorski, J.S., Squillace, P.J., 2007. Chlorinated solvents in groundwater of the United States. Environ. Sci. Technol., 41, 74-81. http://dx.doi.org/10.1021/es061553y

Moser, D.P., Fredrickson, J.K., Geist, D.R., Arntzen, E.V., Peacock, A.D., Li, S.-M.W., Spadoni, T., McKinley, J.P., 2003. Biogeochemical processes and microbial characteristics across groundwater-surface water boundaries of the Hanford Reach of the Columbia River. Environ. Sci. Technol., 37, 5127-34. http://dx.doi.org/10.1021/es034457v

Pankow, J.F., Cherry, J.A., 1996. Dense chlorinated solvents and other DNAPLs in Groundwater. Waterloo Press, Portland, OR, ISBN 0-9648014-1-8, 522 pp.

Pantazidou, M., Panagiotakis, I., Mamais, D., Zikidi, V., 2012. Chloroethene biotransformation in the presence of different sulfate concentrations. Groundwater 32, 106-119. http://dx.doi.org/10.1111/j.1745$\underline{6592.2011 .01372 . \mathrm{X}}$

Pugsley, C.W., Hynes, H.B.N., 1983. A modified freeze-core technique to quantify the depth distribution of fauna in stony streambeds. Canadian Journal of Fisheries and Aquatic Sciences, 1983, 40(5), 637-643. http://dx.doi.org/10.1139/f83-084 
Rathbun, R.E., 2002. Transport, behaviour and fate of volatile organic compounds in streams. U.S. Geological Survey Professional Paper 1589.

http://citeseerx.ist.psu.edu/viewdoc/download?doi=10.1.1.145.9135\&rep=rep1\&type=pdf

Rivett, M.O., Dearden, R.A., Wealthall, G.P., 2014. Architecture, persistence and dissolution of a 20 to 45 year old trichloroethene DNAPL source zone. J. Contam. Hydrol., http://dx.doi.org/10.1016/j.jconhyd.2014.09.008

Rivett, M.O., Ellis, P.A., Mackay, R., 2011. Urban groundwater baseflow influence upon inorganic riverwater quality: the River Tame headwaters catchment in the City of Birmingham, UK. J. Hydrol. 400 (1-2), 206-222. http://dx.doi.org/10.1016/j.jhydrol.2011.01.036

Rivett, M.O., Ellis, P.A., Greswell, R.B., Ward, R.S., Roche, R.S., Cleverly, M., Walker, C., Conran, D., Fitzgerald, P.J., Willcox, T., Dowle, J., 2008. Cost-effective mini drive-point piezometers and multilevel samplers for monitoring the hyporheic zone. Q. J. Eng. Geol. Hydrogeol., 41(1) 49-60. http://dx.doi.org/10.1144/1470-9236/07-012

Rivett, M.O., Feenstra, S, Clark, L., 2006. Lyne and McLachlan (1949): Influence of the first publication on groundwater contamination by trichloroethene. Environ. Forensics, 7(4), 313-323. http://dx.doi.org/10.1080/15275920600996180

Rivett, M.O., Lerner, D.N., Lloyd, J.W., 1990a. Temporal variations of chlorinated solvents in abstraction wells. Ground Water Monitoring Review, 10(4), 127-133. http://dx.doi.org/10.1111/j.17456592.1990.tb00029.x

Rivett, M.O., Lerner, D.N., Lloyd, J.W., Clark, L., 1990b. Organic contamination of the Birmingham aquifer, U.K. Journal of Hydrology, 113, 307-323. http://dx.doi.org/10.1016/0022-1694(90)90181-V

Rivett, M.O., Shepherd, K.A., Keeys, L., Brennan, A.E., 2005. Chlorinated Solvents in the Birmingham Aquifer, UK: 1986 - 2001. Q. J. Eng. Geol. Hydrogeol., 38(4), 337-350. http://dx.doi.org/10.1144/1470$\underline{9236 / 04-051}$

Rivett, M.O., Turner, R.J., Cuthbert, M.O., Glibbery, P., 2012. The legacy of chlorinated solvents in the Birmingham aquifer, UK: Observations spanning three decades and the challenge of future urban groundwater development. J. Contam. Hydrol., 140-141, 107-123. http://dx.doi.org/10.1016/j.jconhyd.2012.08.006

Robinson, C., Barry, D.A., McCarty, P.L., Gerhard, J.I., Kouznetsova, I., 2009. pH control for enhanced reductive bioremediation of chlorinated solvent source zones. Science of the Total Environment, 407 (16), 4560-4573. http://dx.doi.org/10.1016/j.scitotenv.2009.03.029

Roche, R.S., Rivett, M.O., Tellam, J.H., Cleverly, M.G., Walker, M., 2008. Natural attenuation of a TCE plume at the groundwater - surface-water interface: spatial and temporal variability within a $50 \mathrm{~m}$ reach. In: GQ07: Securing Groundwater Quality in Urban and Industrial Environments, IAHS Publ. 324, 475 - 482.

Sanders, I.A., Heppell, C.M., Cotton, J.A., Wharton, G., Hildrew, A.G., Flowers, E.J., Trimmer, M., 2007. Emission of methane from chalk streams has potential implications for agricultural practices. Freshwater Biol., 52, 1176 - 1186. http://dx.doi.org/10.1111/j.1365-2427.2007.01745.x

Scheutz, C., Durant, N.D., Hansen, M.H., Bjerg, P.L., 2011. Natural and enhanced anaerobic degradation of 1,1,1-trichloroethane and its degradation products in the subsurface. A critical review. Water Research 45, 2701-23. http://dx.doi.org/10.1016/j.watres.2011.02.027

Shepherd, K.A., Ellis, P.A., Rivett, M.O. 2006. Integrated understanding of urban land, groundwater, baseflow and surface-water quality - The City of Birmingham, UK. Science of the Total Environment, 360, 180-195. http://dx.doi.org/10.1016/j.scitotenv.2005.08.052 
Smith, J.W.N., Lerner D.N., 2008. Geomorphologic control on pollutant retardation at the groundwater surface water interface. Hydrol. Process. 22, 4679-4694. http://dx.doi.org/10.1002/hyp.7078

Song, J.,X., Chen, X.H., Cheng, C., Wang, D.M., Lackey, S., Xu, Z.X., 2009. Feasibility of grain-size analysis methods for determination of vertical hydraulic conductivity of streambeds. J. Hydrol., 375(3-4), 428-437. http://dx.doi.org/10.1016/j.jhydrol.2009.06.043

Tellam, J.H., 2007. Urban groundwater quality sustainability: the case of Birmingham, England. Zbl. Geol. Paläont. Teil I, 71-86.

US EPA, 2012. Toxicological review of Tetrachloroethylene (Perchloroethylene). Report EPA/635/R08/011F. Available at www.epa.gov/iris/toxreviews/0106tr.pdf

Vedrina-Dragojević, I., Dragojević, D., 1997. Trichloroethene and tetrachloroethene in ground waters of Zagreb, Croatia. Science of the Total Environment, 203, 3, 253-259. http://dx.doi.org/10.1016/S0048$\underline{\text { 9697(97)00153-8 }}$

Vogel, T.M., Criddle, C.S., McCarty, P.L., 1987. ES\&T critical reviews: transformations of halogenated aliphatic compounds. Environ. Sci. Technol., 21(8), 722-736. http://dx.doi.org/10.1021/es00162a001

Vogel, T. M., McCarty, P.L., 1985. Biotransformation of tetrachloroethylene to trichloroethylene, dichloroethylene, vinyl chloride, and carbon dioxide under methanogenic conditions. Appl. Environ. Microbiol., 49(5), 1080-1083.

Weatherill, J., Krause, S., Voyce, K., Drijfhout, F., Levy, A., Cassidy, N., 2014. Nested monitoring approaches to delineate groundwater trichloroethene discharge to a UK lowland stream at multiple spatial scales. J. Contam. Hydrol., 158, 38-54. http://dx.doi.org/10.1016/j.jconhyd.2013.12.001

Weaver, J.W., Wilson, J.T., Kampbell, D.H., 1997. Case study of natural attenuation of trichloroethene at St. Joseph, Michigan, in: Proceedings of the Symposium on Natural Attenuation of Chlorinated Organics in Ground Water. USEPA, Washington, DC, pp. 67-70.

White, R.A., Rivett, M.O., Tellam, J.H., 2008. Paleo-roothole facilitated transport of aromatic hydrocarbons through a Holocene clay bed. Environ. Sci. Technol., 42(19), 7118-7124.

http://dx.doi.org/10.1021/es800797u

Yang, Y., McCarty, P.L., 1998. Competition for hydrogen within a chlorinated solvent dehalogenating anaerobic mixed culture. Environ. Sci. Technol., 32, 3591-3597. http://dx.doi.org/10.1021/es980363n

Yang, Y., McCarty, P.L., 2000. Biomass, oleate, and other possible substrates for chloroethene reductive dehalogenation. Bioremediation Journal. 4(2), 125-133. http://dx.doi.org/10.1080/10889860091114185 